ARTICLE

https://doi.org/10.1038/s41467-020-17216-2

\title{
Photocatalytic hydrogen peroxide splitting on metal-free powders assisted by phosphoric acid as a stabilizer
}

Yasuhiro Shiraishi (10 ${ }^{1 凶}$, Yuki Ueda ${ }^{1}$, Airu Soramoto ${ }^{1}$, Satoshi Hinokuma (i) $^{2}$ \& Takayuki Hirai (i) ${ }^{1}$

Hydrogen peroxide $\left(\mathrm{H}_{2} \mathrm{O}_{2}\right)$ has received increasing attention as an energy carrier. To achieve a sustainable energy society, photocatalytic $\mathrm{H}_{2} \mathrm{O}_{2}$ splitting $\left(\mathrm{H}_{2} \mathrm{O}_{2}(\mathrm{I}) \rightarrow \mathrm{H}_{2}(\mathrm{~g})+\mathrm{O}_{2}(\mathrm{~g})\right.$; $\left.\Delta G^{\circ}=+131 \mathrm{~kJ} \mathrm{~mol}^{-1}\right)$ is a desirable reaction for on-site $\mathrm{H}_{2}$ generation. However, this reaction has not been reported because conventional photocatalysis decomposes $\mathrm{H}_{2} \mathrm{O}_{2}$ by disproportionation $\left(\mathrm{H}_{2} \mathrm{O}_{2}(\mathrm{I}) \rightarrow \mathrm{H}_{2} \mathrm{O}(\mathrm{I})+1 / 2 \mathrm{O}_{2}(\mathrm{~g}) ; \Delta \mathrm{G}^{\circ}=-117 \mathrm{~kJ} \mathrm{~mol}{ }^{-1}\right)$ and by promoting $\mathrm{H}_{2} \mathrm{O}_{2}$ reduction instead of $\mathrm{H}^{+}$reduction. Here we report the successful example of $\mathrm{H}_{2} \mathrm{O}_{2}$ splitting. Visible light irradiation of a graphitic carbon nitride loaded with graphene quantum dots as co-catalysts ( $G Q D s / g-\mathrm{C}_{3} \mathrm{~N}_{4}$ ) in a $\mathrm{H}_{2} \mathrm{O}_{2}$ solution containing phosphoric acid $\left(\mathrm{H}_{3} \mathrm{PO}_{4}\right.$ ) produces $\mathrm{H}_{2} . \mathrm{H}_{3} \mathrm{PO}_{4}$ associates with $\mathrm{H}_{2} \mathrm{O}_{2}$ via hydrogen bonding, and this stabilization of $\mathrm{H}_{2} \mathrm{O}_{2}$ suppresses its reduction, thus promoting $\mathrm{H}^{+}$reduction. The all-organic photosystem with $\mathrm{H}_{3} \mathrm{PO}_{4}$ as a stabilizer may provide a basis of photocatalytic $\mathrm{H}_{2} \mathrm{O}_{2}$ splitting.

\footnotetext{
${ }^{1}$ Research Center for Solar Energy Chemistry, and Division of Chemical Engineering, Graduate School of Engineering Science, Osaka University, Toyonaka 560-8531, Japan. ${ }^{2}$ Division of Materials Science and Chemistry, Faculty of Advanced Science and Technology, Kumamoto University, Kumamoto 860-8555,

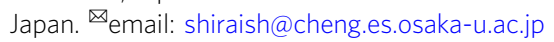


A rtificial photosynthesis, which transforms earth-abundant resources into fuels by sunlight, is an urgent and challenging issue for realizing a sustainable energy society ${ }^{1,2}$. In the last 50 years, photocatalytic water splitting for hydrogen $\left(\mathrm{H}_{2}\right)$ generation under sunlight irradiation (Eq. (1)) has been extensively studied for this purpose ${ }^{3-5}$. However, $\mathrm{H}_{2}$ gas has a low volumetric energy density and needs to be converted into a storable and transportable liquid energy carrier such as an organic hydride ${ }^{6}$ and ammonia ${ }^{7}$. Therefore, identifying a new artificial photosynthesis system that directly generates a liquid energy carrier is a challenge. Recently, hydrogen peroxide $\left(\mathrm{H}_{2} \mathrm{O}_{2}\right)$ has received increasing attention as a new liquid energy carrier because it is storable and transportable and generates electricity in a direct peroxide-peroxide fuel cell (DPPFC), although careful handling is necessary owing to its property of being decomposed in the presence of some metal impurities or under heating conditions ${ }^{8}$. The most attractive feature is that $\mathrm{H}_{2} \mathrm{O}_{2}$ can be generated from earth-abundant water and oxygen $\left(\mathrm{O}_{2}\right)$ via photocatalysis ${ }^{9-11}$. The photogenerated valence band holes $\left(\mathrm{VB} \mathrm{h}^{+}\right)$ oxidize water $\left(\mathrm{O}_{2}\right.$ generation) and the conduction band electrons $\left(\mathrm{CB} \mathrm{e}^{-}\right)$reduce $\mathrm{O}_{2} \quad\left(\mathrm{H}_{2} \mathrm{O}_{2}\right.$ generation). These reactions generate $\mathrm{H}_{2} \mathrm{O}_{2}$ by sunlight irradiation under ambient conditions with a positive Gibbs free energy change (Eq. (2)). Therefore, photocatalytic $\mathrm{H}_{2} \mathrm{O}_{2}$ generation is a new potential candidate for artificial photosynthesis. Recently, we reported that the resorcinol-formaldehyde resins prepared by the high-temperature hydrothermal synthesis could successfully catalyze the above-mentioned reactions on absorbing visible light up to 620 $\mathrm{nm}^{12}$. Further, these metal-free resins stably produced $\mathrm{H}_{2} \mathrm{O}_{2}$ with $0.5 \%$ of solar-to-chemical conversion efficiency, which is comparable to the highest efficiency for photocatalytic water splitting (Eq. (1)) by metal-based powder photocatalysts ${ }^{13}$. Therefore, $\mathrm{H}_{2} \mathrm{O}_{2}$ is a new promising liquid energy carrier candidate.

$$
\begin{gathered}
\mathrm{H}_{2} \mathrm{O}(\mathrm{l}) \stackrel{h v}{\longrightarrow} \mathrm{H}_{2}(\mathrm{~g})+1 / 2 \mathrm{O}_{2}(\mathrm{~g})\left(\Delta G^{\circ}=+237 \mathrm{~kJ} \mathrm{~mol}^{-1}\right) \\
\mathrm{H}_{2} \mathrm{O}(\mathrm{l})+1 / 2 \mathrm{O}_{2}(\mathrm{~g}) \stackrel{h v}{\longrightarrow} \mathrm{H}_{2} \mathrm{O}_{2}(\mathrm{l})\left(\Delta G^{\circ}=+117 \mathrm{~kJ} \mathrm{~mol}^{-1}\right)
\end{gathered}
$$

To realize a sustainable energy society with $\mathrm{H}_{2} \mathrm{O}_{2}$, on-site generation of $\mathrm{H}_{2}$ from $\mathrm{H}_{2} \mathrm{O}_{2}$ solution is necessary also for its use as a hydrogen carrier. Theoretically, semiconductor photocatalysis can promote the overall $\mathrm{H}_{2} \mathrm{O}_{2}$ splitting. The photogenerated $\mathrm{VB} \mathrm{h}{ }^{+}$oxidize $\mathrm{H}_{2} \mathrm{O}_{2}$ to produce $\mathrm{O}_{2}$ (Eq. (3)), and the $\mathrm{CB} \mathrm{e}^{-}$reduce $\mathrm{H}^{+}$to form $\mathrm{H}_{2}$ (Eq. (4)). These redox reactions lead to the generation of $\mathrm{H}_{2}$ from $\mathrm{H}_{2} \mathrm{O}_{2}$ under sunlight at ambient temperature (Eq. (5)). Owing to the relatively large Gibbs free energy gain $\left(\Delta G^{\circ}=+131 \mathrm{~kJ} \mathrm{~mol}^{-1}\right), \mathrm{H}_{2} \mathrm{O}_{2}$ splitting is potentially a new type of artificial photosynthesis reaction. Despite these advantages, photocatalytic $\mathrm{H}_{2} \mathrm{O}_{2}$ splitting is not reported. This is because $\mathrm{H}_{2} \mathrm{O}_{2}$ readily decomposes into water and $\mathrm{O}_{2}$ over conventional $\mathrm{H}_{2}$ generation photocatalysts even under dark conditions by disproportionation (Eq. (6)) on the surfaces of metaloxide semiconductors (such as $\mathrm{TiO}_{2}$ ) or of metal particle co-catalysts (such as $\mathrm{Pt}$ ) ${ }^{14-16}$. Other reasons are that $\mathrm{H}_{2} \mathrm{O}_{2}$ is decomposed into hydroxyl radicals on ultraviolet (UV) light absorption at $\lambda<400 \mathrm{~nm}$ (Eq. (7) $)^{17,18}$, and $\mathrm{CB} \mathrm{e}^{-}$reduce $\mathrm{H}_{2} \mathrm{O}_{2}$ (Eqs. (8) and (9)) more efficiently than $\mathrm{H}^{+}$(Eq. (4)), owing to their low-lying reduction potentials ${ }^{19}$. The design of visible-lightdriven metal-free photocatalytic systems that can selectively reduce $\mathrm{H}^{+}$while suppressing $\mathrm{H}_{2} \mathrm{O}_{2}$ reduction is necessary.

$$
\begin{gathered}
\mathrm{H}_{2} \mathrm{O}_{2}(\mathrm{l})+2 \mathrm{~h}^{+} \rightarrow \mathrm{O}_{2}(\mathrm{~g})+2 \mathrm{H}^{+}(\mathrm{aq})(+0.68 \mathrm{~V} \text { vs } \mathrm{NHE}) \\
2 \mathrm{H}^{+}(\mathrm{aq})+2 \mathrm{e}^{-} \rightarrow \mathrm{H}_{2}(\mathrm{~g})(0 \mathrm{~V} \text { vs NHE })
\end{gathered}
$$

$$
\begin{gathered}
\mathrm{H}_{2} \mathrm{O}_{2}(\mathrm{l}) \stackrel{h v}{\longrightarrow} \mathrm{H}_{2}(\mathrm{~g})+\mathrm{O}_{2}(\mathrm{~g})\left(\Delta G^{\circ}=+131 \mathrm{~kJ} \mathrm{~mol}^{-1}\right) \\
\mathrm{H}_{2} \mathrm{O}_{2}(\mathrm{l}) \rightarrow \mathrm{H}_{2} \mathrm{O}(\mathrm{l})+1 / 2 \mathrm{O}_{2}(\mathrm{~g})\left(\Delta G^{\circ}=-117 \mathrm{~kJ} \mathrm{~mol}^{-1}\right) \\
\mathrm{H}_{2} \mathrm{O}_{2}(\mathrm{l}) \stackrel{h v(\lambda<400 \mathrm{~nm})}{\longrightarrow} 2 \cdot \mathrm{OH}(\mathrm{aq}) \\
\mathrm{H}_{2} \mathrm{O}_{2}(\mathrm{l})+\mathrm{H}^{+}(\mathrm{aq})+\mathrm{e}^{-} \rightarrow \mathrm{H}_{2} \mathrm{O}(\mathrm{l})+\cdot \mathrm{OH}(\mathrm{aq})(+1.14 \mathrm{~V} \text { vs NHE})
\end{gathered}
$$

$$
\mathrm{H}_{2} \mathrm{O}_{2}(\mathrm{l})+2 \mathrm{H}^{+}(\mathrm{aq})+2 \mathrm{e}^{-} \rightarrow \mathrm{H}_{2} \mathrm{O}(\mathrm{l})(+1.76 \mathrm{~V} \text { vs NHE })
$$

Herein, we report the successful example of photocatalytic $\mathrm{H}_{2} \mathrm{O}_{2}$ splitting. To avoid the undesirable $\mathrm{H}_{2} \mathrm{O}_{2}$ disproportionation (Eq. (6)), we used a graphitic carbon nitride $\left(g-\mathrm{C}_{3} \mathrm{~N}_{4}\right)$ organic semiconductor ${ }^{20}$. The $\mathrm{g}-\mathrm{C}_{3} \mathrm{~N}_{4}$ is less active for $\mathrm{H}_{2} \mathrm{O}_{2}$ disproportionation ${ }^{14}$, and its $\mathrm{VB}$ and $\mathrm{CB}$ levels $(+2.00$ and -0.63 $\mathrm{V}$ (vs NHE), respectively) are sufficient for $\mathrm{H}_{2} \mathrm{O}_{2}$ oxidation (Eq. (3)) and $\mathrm{H}^{+}$reduction (Eq. (4)). We also used graphene quantum dots (GQDs) as co-catalysts; these are the carbon materials belonging to the graphene family and have attracted increasing attention as non-metal $\mathrm{H}_{2}$ evolution co-catalysts owing to their high electron conductivity and electron reservation capacity ${ }^{21-24}$. Visible-light irradiation of the GQD/g- $\mathrm{C}_{3} \mathrm{~N}_{4}$ catalyst in a $\mathrm{H}_{2} \mathrm{O}_{2}$ solution containing phosphoric acid $\left(\mathrm{H}_{3} \mathrm{PO}_{4}\right)$ at a relatively low temperature $(\sim 293 \mathrm{~K})$ successfully produced $\mathrm{H}_{2}$. The addition of $\mathrm{H}_{3} \mathrm{PO}_{4}$, which is used as a stabilizer for commercially available $\mathrm{H}_{2} \mathrm{O}_{2}$ solution ${ }^{25,26}$, plays a pivotal role in this reaction. Raman spectroscopy and ab initio calculations revealed that $\mathrm{H}_{3} \mathrm{PO}_{4}$ associates with $\mathrm{H}_{2} \mathrm{O}_{2}$ via hydrogen bonding. The stabilization of $\mathrm{H}_{2} \mathrm{O}_{2}$ by $\mathrm{H}_{3} \mathrm{PO}_{4}$ inhibited $\mathrm{H}_{2} \mathrm{O}_{2}$ reduction (Eqs. (8) and (9)) and, hence, promoted $\mathrm{H}^{+}$reduction (Eq. (4)), resulting in successful $\mathrm{H}_{2}$ generation.

\section{Results}

Preparation and characterization of catalyst. $\mathrm{g}-\mathrm{C}_{3} \mathrm{~N}_{4}$ powder was prepared by calcination of melamine ${ }^{27}$. The GQDs solution was produced by the reduction of nitrated pyrene with hydrazine followed by hydrothermal treatment ${ }^{23}$. The GQD $\mathrm{G}_{x} / \mathrm{g}-\mathrm{C}_{3} \mathrm{~N}_{4}$ catalyst was prepared by the hydrothermal treatment of a GQDs solution containing $g-\mathrm{C}_{3} \mathrm{~N}_{4}$, where $x$ denotes the amount of GQDs-loaded relative to that of $g-\mathrm{C}_{3} \mathrm{~N}_{4}\left[x(\mathrm{wt} \%)=\mathrm{GQDs} / \mathrm{g}-\mathrm{C}_{3} \mathrm{~N}_{4} \times 100\right]$. In the $\mathrm{UV}$-visible absorption spectra of the solution (Supplementary Fig. 1), the absorption band at $\lambda>500 \mathrm{~nm}$ for GQDs ${ }^{28}$ almost disappears completely after hydrothermal treatment with $g-\mathrm{C}_{3} \mathrm{~N}_{4}$, indicating that almost all of the GQDs in the solutions were successfully loaded on the $\mathrm{g}-\mathrm{C}_{3} \mathrm{~N}_{4}$ surface. In Fig. 1a, the diffusereflectance (DR) UV-visible spectrum of $\mathrm{GQD}_{x} / \mathrm{g}-\mathrm{C}_{3} \mathrm{~N}_{4}$ presents a band at $\lambda<470 \mathrm{~nm}$, which is assigned to the bandgap transition of g- $\mathrm{C}_{3} \mathrm{~N}_{4}$. Increasing the amount of the GQDs loaded increases the absorbance at $\lambda>500 \mathrm{~nm}$, indicating that the GQDs are indeed loaded on the $\mathrm{g}-\mathrm{C}_{3} \mathrm{~N}_{4}$ surface. The bandgap energies of both $\mathrm{g}$ $\mathrm{C}_{3} \mathrm{~N}_{4}$ and $\mathrm{GQD} / \mathrm{g}-\mathrm{C}_{3} \mathrm{~N}_{4}$ were determined to be $\sim 2.6 \mathrm{eV}$ by the Tauc plot analysis (Supplementary Fig. 2), suggesting that the GQDs loading scarcely affects the band structure of $g-\mathrm{C}_{3} \mathrm{~N}_{4}$. The powder X-ray diffraction (XRD) patterns of $\mathrm{g}-\mathrm{C}_{3} \mathrm{~N}_{4}$ and $\mathrm{GQD}_{x} / \mathrm{g}$ $\mathrm{C}_{3} \mathrm{~N}_{4}$ present peaks at $2 \theta=27.4^{\circ}(d=0.325 \mathrm{~nm})$, which are assigned to the (002) packing of the melem sheet (Supplementary Fig. 3) ${ }^{20}$, indicating that these catalysts maintain their layered stacking structure even after the GQDs loading. The scanning electron microscopy (SEM) images of both $g-\mathrm{C}_{3} \mathrm{~N}_{4}$ and $\mathrm{GQD}_{1} / \mathrm{g}$ $\mathrm{C}_{3} \mathrm{~N}_{4}$ (Supplementary Fig. 4) indicate an amorphous solid morphology with similar sizes $(\sim 30 \mu \mathrm{m}$ diameter $)$. The transmission electron microscopy (TEM) results of the GQDs solution (Fig. 2, top) present dispersed GQD particles with $\sim 3-\mathrm{nm}$ 

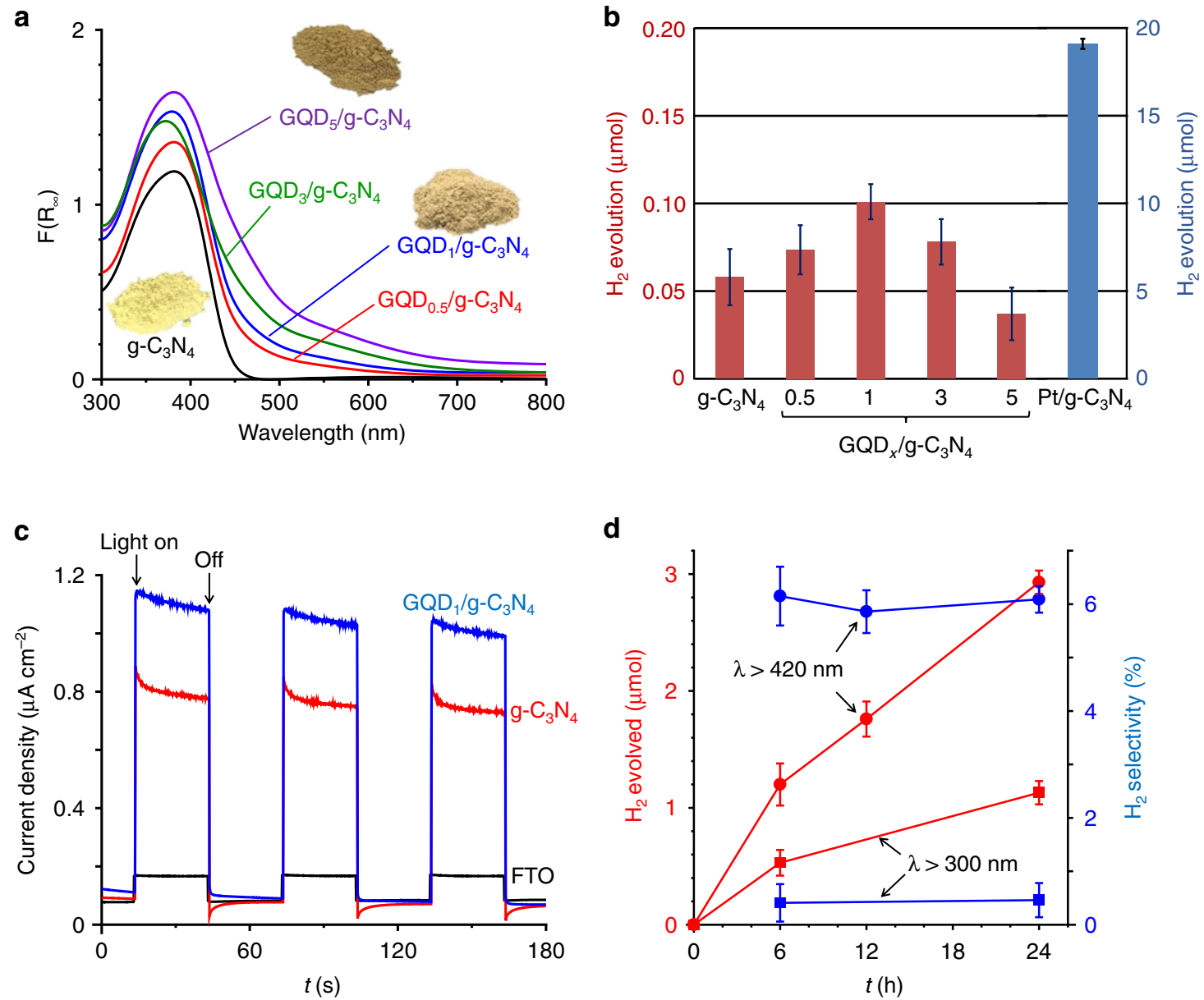

Fig. 1 Properties of $\mathbf{G Q D} \mathbf{x} / \mathbf{g}-\mathbf{C}_{\mathbf{3}} \mathbf{N}_{\mathbf{4}}$ photocatalysts. a DR UV-vis spectra of catalysts. $\mathbf{b}$ Amounts of $\mathrm{H}_{2}$ evolved on the respective catalysts in water containing TEOA as a sacrificial electron donor performed in a closed system ( $0.1 \mathrm{MPa}$ Ar). Conditions: catalyst (100 mg), a water/TEOA ( $9 / 1 \mathrm{v} / \mathrm{v}) \mathrm{mixture}$ $(30 \mathrm{~mL})$, light irradiation ( $\lambda>420 \mathrm{~nm}$, Xe lamp), room temperature, and photoirradiation time $(6 \mathrm{~h})$. Error bars represent standard error (s.e.) determined by three independent experiments. c Photocurrent response of the catalysts measured on an FTO glass in $0.1 \mathrm{M} \mathrm{Na}_{2} \mathrm{SO}_{4}$ solution at a bias of $0.8 \mathrm{~V}$ vs Ag/ $\mathrm{AgCl}$. d Time-dependent change in the amount of $\mathrm{H}_{2}$ evolved and the $\mathrm{H}_{2}$ selectivity during photoirradiation of the entire wavelength light $(\lambda>300 \mathrm{~nm})$ or $\lambda>420 \mathrm{~nm}$ light in a closed gas circulation system ( $3 \mathrm{kPa}$ Ar). Conditions: catalyst (200 mg), $\mathrm{H}_{2} \mathrm{O}_{2}(10 \mathrm{mM}, 100 \mathrm{~mL}), \mathrm{H}_{3} \mathrm{PO}_{4}(1 \mathrm{M})$, temperature $(293 \mathrm{~K})$, and light irradiation (solar simulator with AM $1.5 \mathrm{G}$ filter, 1-sun). Error bars represent standard error (s.e.) determined by three independent experiments.

diameters ${ }^{23,29,30}$. In contrast, the $\mathrm{GQD}_{1} / \mathrm{g}-\mathrm{C}_{3} \mathrm{~N}_{4}$ catalyst (Fig. 2, bottom) has larger GQD particles with $\sim 10$-nm diameters, indicating that the GQD particles are loaded onto the $\mathrm{g}-\mathrm{C}_{3} \mathrm{~N}_{4}$ surface via some aggregation during the hydrothermal treatment.

Effect of GQDs as co-catalysts. The effect of the GQDs on the photocatalytic activity for $\mathrm{H}_{2}$ generation was studied using triethanolamine (TEOA) as a sacrificial electron donor. A TEOA/ water $(1 / 9 \mathrm{v} / \mathrm{v})$ mixture $(30 \mathrm{~mL})$ containing the catalyst $(100 \mathrm{mg})$ was photoirradiated for $6 \mathrm{~h}$ by a xenon lamp $(\lambda>420 \mathrm{~nm})$ with magnetic stirring at room temperature under Ar atmosphere in a closed system $(0.1 \mathrm{MPa})$. Figure $1 \mathrm{~b}$ presents the amount of $\mathrm{H}_{2}$ evolved over the respective catalysts. The loading of GQDs enhances $\mathrm{H}_{2}$ evolution, indicating that the GQDs act as cocatalysts for $\mathrm{H}^{+}$reduction. $\mathrm{GQD}_{1} / \mathrm{g}-\mathrm{C}_{3} \mathrm{~N}_{4}$ exhibits the highest activity; however, further GQDs loading decrease the activity. This decrease is because a larger amount of GQDs absorb more incident light (Fig. 1a) and suppresses the photoexcitation of g$\mathrm{C}_{3} \mathrm{~N}_{4}$. Figure 1c shows the photocurrent responses of the catalysts measured on a fluorine tin oxide (FTO) electrode. The photocurrent density of $\mathrm{GQD}_{1} / \mathrm{g}-\mathrm{C}_{3} \mathrm{~N}_{4}$ is higher than that of $\mathrm{g}-\mathrm{C}_{3} \mathrm{~N}_{4}$, indicating that the $\mathrm{CB} \mathrm{e}^{-}$photogenerated on $\mathrm{g}-\mathrm{C}_{3} \mathrm{~N}_{4}$ are efficiently transferred to the GQDs and electrode ${ }^{31,32}$. The enhanced charge separation of the $\mathrm{h}^{+}$and $\mathrm{e}^{-}$pairs by the GQDs loading, therefore, enhances the activity for $\mathrm{H}_{2}$ evolution. As shown by the blue bar in Fig. $1 \mathrm{~b}, \mathrm{~g}-\mathrm{C}_{3} \mathrm{~N}_{4}$ when loaded with $\mathrm{Pt}$ particles $(\mathrm{Pt} / \mathrm{g}$ $\mathrm{C}_{3} \mathrm{~N}_{4}$ ), a typical noble metal co-catalyst for $\mathrm{H}_{2}$ generation ${ }^{33}$, exhibits a much higher activity than $\mathrm{GQD}_{1} / \mathrm{g}-\mathrm{C}_{3} \mathrm{~N}_{4}$, where the amount of $\mathrm{H}_{2}$ formed is 100 -fold higher than that formed on $\mathrm{GQD}_{1} / \mathrm{g}-\mathrm{C}_{3} \mathrm{~N}_{4}$. The activity of the GQDs as co-catalysts for $\mathrm{H}_{2}$ generation is lower than that of $\mathrm{Pt}$.

Photocatalytic $\mathrm{H}_{2} \mathrm{O}_{2}$ splitting. Photocatalytic $\mathrm{H}_{2} \mathrm{O}_{2}$ splitting was performed in a closed gas circulation system at a reduced pressure $^{34}(3 \mathrm{kPa}$ Ar) under a constant temperature. Visible light $(\lambda>$ $420 \mathrm{~nm}$ ) was irradiated by a solar simulator with an AM1.5 G filter (1-sun) to a $\mathrm{H}_{2} \mathrm{O}_{2}$ solution $(1 \mathrm{mmol}, 100 \mathrm{~mL})$ containing a catalyst $(200 \mathrm{mg})$ at $293 \mathrm{~K}$. Table 1 lists the amounts of $\mathrm{H}_{2}$ and $\mathrm{O}_{2}$ generated and the amount of $\mathrm{H}_{2} \mathrm{O}_{2}$ consumed during $6 \mathrm{~h}$ of photoirradiation. As shown by entry 1, stirring the solution containing $\mathrm{GQD}_{1} / \mathrm{g}-\mathrm{C}_{3} \mathrm{~N}_{4}$ in the dark does not produce $\mathrm{H}_{2}$ or $\mathrm{O}_{2}$ and does not consume $\mathrm{H}_{2} \mathrm{O}_{2}$, indicating that the catalyst is indeed inactive for the disproportionation of $\mathrm{H}_{2} \mathrm{O}_{2}$. As shown by entry 2, photoirradiation of $\mathrm{Pt} / \mathrm{g}-\mathrm{C}_{3} \mathrm{~N}_{4}$ does not produce $\mathrm{H}_{2}$ while decomposing almost the entire $\mathrm{H}_{2} \mathrm{O}_{2}$ and producing a very large amount of $\mathrm{O}_{2}$, suggesting that $\mathrm{Pt}$ significantly promote $\mathrm{H}_{2} \mathrm{O}_{2}$ 
disproportionation (Eq. (6) $)^{14,15}$. As shown by entry 3, photoirradiation of GQD $/ g-\mathrm{C}_{3} \mathrm{~N}_{4}$ in pure water without $\mathrm{H}_{2} \mathrm{O}_{2}$ does not produce $\mathrm{H}_{2}$ or $\mathrm{O}_{2}$ because $\mathrm{g}-\mathrm{C}_{3} \mathrm{~N}_{4}$ is less active for water oxidation by the $\mathrm{VB} \mathrm{h}^{+}$due to its relatively negative $\mathrm{VB}$ level ${ }^{35}$. As exhibited by entry 4 , photoirradiation of $\mathrm{GQD}_{1} / \mathrm{g}-\mathrm{C}_{3} \mathrm{~N}_{4}$ in a $\mathrm{H}_{2} \mathrm{O}_{2}$ solution also does not produce $\mathrm{H}_{2}$ while promoting $\mathrm{O}_{2}$ production $(17 \mu \mathrm{mol})$ and $\mathrm{H}_{2} \mathrm{O}_{2}$ consumption $(30 \mu \mathrm{mol})$, suggesting that the $\mathrm{CB} \mathrm{e}^{-}$do not reduce $\mathrm{H}^{+}$(Eq. (4)) although the $\mathrm{VB} \mathrm{h}^{+}$oxidize $\mathrm{H}_{2} \mathrm{O}_{2}$ (Eq. (3)). This is because the $\mathrm{CB} \mathrm{e}^{-}$reduce $\mathrm{H}_{2} \mathrm{O}_{2}$ (Eqs. (8)

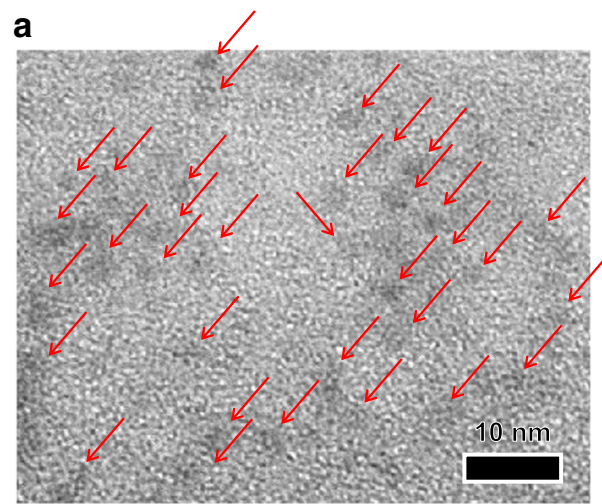

b

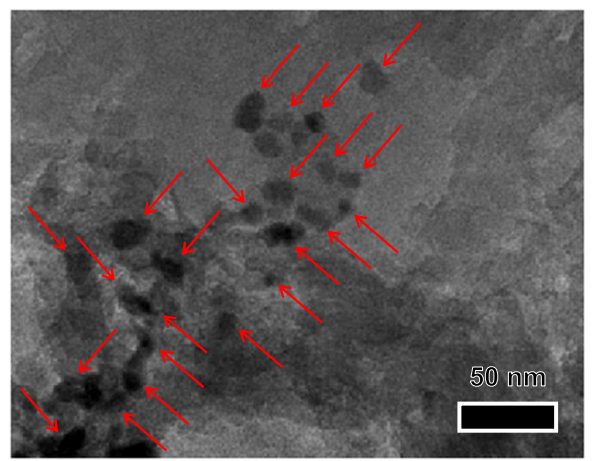

Fig. 2 Typical TEM images. a GQD solution. $\mathbf{b} G Q D_{1} / g-C_{3} N_{4}$ catalyst. The red arrows are the guide for the eyes to follow the GQD particles. and (9)) more efficiently than $\mathrm{H}^{+}$reduction (Eq. (4)), owing to their low-lying reduction potentials ${ }^{19}$. The $\mathrm{H}_{2} \mathrm{O}_{2}$ reduction by $\mathrm{CB}$ $\mathrm{e}^{-}$must therefore be suppressed to promote $\mathrm{H}^{+}$reduction.

Effect of $\mathbf{H}_{3} \mathbf{P O}_{4}$. It is well known that $\mathrm{H}_{3} \mathrm{PO}_{4}$ is generally added to commercially available $\mathrm{H}_{2} \mathrm{O}_{2}$ solutions as a stabilizer to inhibit the decomposition of $\mathrm{H}_{2} \mathrm{O}_{2}{ }^{36,37}$. Therefore, we studied the effect of $\mathrm{H}_{3} \mathrm{PO}_{4}$ on the photocatalytic $\mathrm{H}_{2} \mathrm{O}_{2}$ splitting. As exhibited by entries 5-7, visible-light irradiation of $\mathrm{GQD}_{1} / \mathrm{g}-\mathrm{C}_{3} \mathrm{~N}_{4}$ in a $\mathrm{H}_{2} \mathrm{O}_{2}$ solution containing $\mathrm{H}_{3} \mathrm{PO}_{4}$ produces $\mathrm{H}_{2}$. This is the first successful example of photocatalytic $\mathrm{H}_{2} \mathrm{O}_{2}$ splitting. The photocatalytic activity depends on the amount of $\mathrm{H}_{3} \mathrm{PO}_{4}$ added. The addition of $1 \mathrm{M} \mathrm{H}_{3} \mathrm{PO}_{4}$ (entry 6) produces the largest amount of $\mathrm{H}_{2}(1.2 \mu \mathrm{mol})$, but further addition (entry 7$)$ decreases the activity. Several types of reagents such as $\mathrm{H}_{3} \mathrm{PO}_{3}{ }^{37}$, uric acid ${ }^{38}$, $\mathrm{Na}_{2} \mathrm{CO}_{3}{ }^{39}, \mathrm{KHCO}_{3}{ }^{40}$, barbituric acid ${ }^{41}$, hippuric acid ${ }^{42}$, urea, and acetanilide $^{43}$ have also been reported to serve as stabilizers for $\mathrm{H}_{2} \mathrm{O}_{2}$. However, as shown in Supplementary Table 1, the photoirradiation of $\mathrm{GQD}_{1} / \mathrm{g}-\mathrm{C}_{3} \mathrm{~N}_{4}$ in a $\mathrm{H}_{2} \mathrm{O}_{2}$ solution containing each of the respective reagents barely produces $\mathrm{H}_{2}$, indicating that $\mathrm{H}_{3} \mathrm{PO}_{4}$ is specifically effective for photocatalytic $\mathrm{H}_{2} \mathrm{O}_{2}$ splitting. The $\mathrm{pH}$ of $1 \mathrm{M} \mathrm{H}_{3} \mathrm{PO}_{4}$ solution is $\sim 1.0$. As presented by entry 8 , the photoreaction, when performed in a $\mathrm{H}_{2} \mathrm{O}_{2}$ solution with $\mathrm{H}_{2} \mathrm{SO}_{4}(0.1 \mathrm{M}, \mathrm{pH} \sim 1)$, does not produce $\mathrm{H}_{2}$. This indicates that a low $\mathrm{pH}$ is not a critical factor for enhanced $\mathrm{H}_{2}$ generation with $\mathrm{H}_{3} \mathrm{PO}_{4}$. As exhibited by entry 7, addition of more $\mathrm{H}_{3} \mathrm{PO}_{4}(2 \mathrm{M})$ decreases the amount of $\mathrm{H}_{2}$ generated. In this case, the amounts of $\mathrm{O}_{2}$ generated and $\mathrm{H}_{2} \mathrm{O}_{2}$ consumed also decrease because the $\mathrm{H}^{+}$concentration increased by a larger amount of $\mathrm{H}_{3} \mathrm{PO}_{4}(\mathrm{pH}$ 0.7) suppresses the $\mathrm{H}_{2} \mathrm{O}_{2}$ oxidation by the $\mathrm{VB} \mathrm{h}^{+}$(Eq. (3)). These data imply that $\mathrm{H}_{3} \mathrm{PO}_{4}$ may interact with $\mathrm{H}_{2} \mathrm{O}_{2}$ and inhibit its reduction (Eqs. (8) and (9)), resulting in the promotion of $\mathrm{H}^{+}$ reduction (Eq. (4)). As shown by entry 9 , the $\mathrm{Pt} / \mathrm{g}-\mathrm{C}_{3} \mathrm{~N}_{4}$ catalyst, when photoirradiated with $1 \mathrm{M} \mathrm{H}_{3} \mathrm{PO}_{4}$, produces $\mathrm{H}_{2}$; however, in the absence of $\mathrm{H}_{3} \mathrm{PO}_{4}, \mathrm{H}_{2}$ is not produced (entry 2). This confirms that $\mathrm{H}_{3} \mathrm{PO}_{4}$ interacts with $\mathrm{H}_{2} \mathrm{O}_{2}$ and inhibits the $\mathrm{H}_{2} \mathrm{O}_{2}$ reduction by the $\mathrm{CB} \mathrm{e}^{-}$; however, the amount of $\mathrm{H}_{2}$ formed $(0.2$ $\mu \mathrm{mol})$ is much smaller than that formed over $\mathrm{GQD}_{1} / \mathrm{g}_{-} \mathrm{C}_{3} \mathrm{~N}_{4}(1.2$ $\mu \mathrm{mol}$, entry 6). In this case, almost the entire $\mathrm{H}_{2} \mathrm{O}_{2}(1 \mathrm{mmol})$ is decomposed, similar to the case without $\mathrm{H}_{3} \mathrm{PO}_{4}$ (entry 2), indicating that $\mathrm{Pt}$ particles inevitably promote $\mathrm{H}_{2} \mathrm{O}_{2}$

Table 1 Results of photocatalytic $\mathrm{H}_{2} \mathrm{O}_{2}$ splitting.

\begin{tabular}{|c|c|c|c|c|c|c|c|}
\hline Entry & Temperature (K) & Catalyst & Light & Additive & $\mathrm{H}_{2}$ ( $\left.\mu \mathrm{mol}\right)$ & $\mathrm{O}_{2}$ ( $\left.\mu \mathrm{mol}\right)$ & Consumed $\mathrm{H}_{2} \mathrm{O}_{2}(\mu \mathrm{mol})$ \\
\hline 1 & 293 & $\mathrm{GQD}_{1} / \mathrm{g}-\mathrm{C}_{3} \mathrm{~N}_{4}$ & & & N.D. & N.D. & $<0.1$ \\
\hline 2 & 293 & $\mathrm{Pt} / \mathrm{g}-\mathrm{C}_{3} \mathrm{~N}_{4}$ & $>420 \mathrm{~nm}$ & & N.D. & 125 & $>999^{a}$ \\
\hline $3^{b}$ & 293 & $\mathrm{GQD}_{1} / \mathrm{g}-\mathrm{C}_{3} \mathrm{~N}_{4}$ & $>420 \mathrm{~nm}$ & & N.D. & N.D. & \\
\hline 4 & 293 & $\mathrm{GQD}_{1} / \mathrm{g}-\mathrm{C}_{3} \mathrm{~N}_{4}$ & $>420 \mathrm{~nm}$ & & N.D. & 17.3 & 30 \\
\hline 5 & 293 & $\mathrm{GQD}_{1} / \mathrm{g}-\mathrm{C}_{3} \mathrm{~N}_{4}$ & $>420 \mathrm{~nm}$ & $\mathrm{H}_{3} \mathrm{PO}_{4}(0.5 \mathrm{M})^{\mathrm{C}}$ & 0.4 & 16.9 & 28 \\
\hline 6 & 293 & $\mathrm{GQD}_{1} / \mathrm{g}-\mathrm{C}_{3} \mathrm{~N}_{4}$ & $>420 \mathrm{~nm}$ & $\mathrm{H}_{3} \mathrm{PO}_{4}(1 \mathrm{M})^{\mathrm{d}}$ & 1.2 & 7.7 & 20 \\
\hline 7 & 293 & $\mathrm{GQD}_{1} / \mathrm{g}-\mathrm{C}_{3} \mathrm{~N}_{4}$ & $>420 \mathrm{~nm}$ & $\mathrm{H}_{3} \mathrm{PO}_{4}(2 \mathrm{M})^{\mathrm{e}}$ & 0.3 & 4.2 & 13 \\
\hline 8 & 293 & $\mathrm{GQD}_{1} / \mathrm{g}-\mathrm{C}_{3} \mathrm{~N}_{4}$ & $>420 \mathrm{~nm}$ & $\mathrm{H}_{2} \mathrm{SO}_{4}(0.1 \mathrm{M})^{d}$ & N.D. & 15.6 & 25 \\
\hline 9 & 293 & $\mathrm{Pt} / \mathrm{g}-\mathrm{C}_{3} \mathrm{~N}_{4}$ & $>420 \mathrm{~nm}$ & $\mathrm{H}_{3} \mathrm{PO}_{4}(1 \mathrm{M})$ & 0.2 & 251 & $>999^{a}$ \\
\hline 10 & 293 & $\mathrm{GQD}_{1} / \mathrm{g}-\mathrm{C}_{3} \mathrm{~N}_{4}$ & $>420 \mathrm{~nm}$ & $\mathrm{NaH}_{2} \mathrm{PO}_{4}(1 \mathrm{M})^{f}$ & 0.4 & 49.6 & 78 \\
\hline 11 & 303 & $\mathrm{GQD}_{1} / \mathrm{g}-\mathrm{C}_{3} \mathrm{~N}_{4}$ & $>420 \mathrm{~nm}$ & $\mathrm{H}_{3} \mathrm{PO}_{4}(1 \mathrm{M})$ & 0.5 & 9.4 & 20 \\
\hline 12 & 313 & $\mathrm{GQD}_{1} / \mathrm{g}-\mathrm{C}_{3} \mathrm{~N}_{4}$ & $>420 \mathrm{~nm}$ & $\mathrm{H}_{3} \mathrm{PO}_{4}(1 \mathrm{M})$ & N.D. & 10.8 & 21 \\
\hline 13 & 323 & $\mathrm{GQD}_{1} / \mathrm{g}-\mathrm{C}_{3} \mathrm{~N}_{4}$ & $>420 \mathrm{~nm}$ & $\mathrm{H}_{3} \mathrm{PO}_{4}(1 \mathrm{M})$ & N.D. & 8.8 & 25 \\
\hline 14 & 293 & $\mathrm{GQD}_{1} / \mathrm{g}-\mathrm{C}_{3} \mathrm{~N}_{4}$ & $>300 \mathrm{~nm}$ & $\mathrm{H}_{3} \mathrm{PO}_{4}(1 \mathrm{M})$ & 0.5 & 22.1 & 127 \\
\hline
\end{tabular}

Reactions were performed in a closed gas circulation system ( $3 \mathrm{kPa} \mathrm{Ar}$ ). Conditions are: catalyst $\left(200 \mathrm{mg}\right.$ ), light source (solar simulator, 1-sun), $\mathrm{H}_{2} \mathrm{O}_{2}$ solution (1 mmol $\left.(10 \mathrm{mM}), 100 \mathrm{~mL}\right)$, and photoirradiation time $(6 \mathrm{~h}$ ). All of the data are the mean values determined by the multiple experiments (at least three times) and contain $\pm 21 \%$ deviations.

a Most of $\mathrm{H}_{2} \mathrm{O}_{2}$ decomposes while setting up the reactor owing to rapid disproportionation on the Pt particles.

bPure water without $\mathrm{H}_{2} \mathrm{O}_{2}$ was used for the photoreaction.

cThe $\mathrm{pH}$ of the solutions was $\sim 1.2$

dThe $\mathrm{pH}$ of the solution was $\sim 1.0$.

The $\mathrm{pH}$ of the solution was $\sim 0.6$

tThe $\mathrm{pH}$ of the solution was adjusted to $\sim 1.0$ by the addition of $\mathrm{H}_{2} \mathrm{SO}_{4}$. 


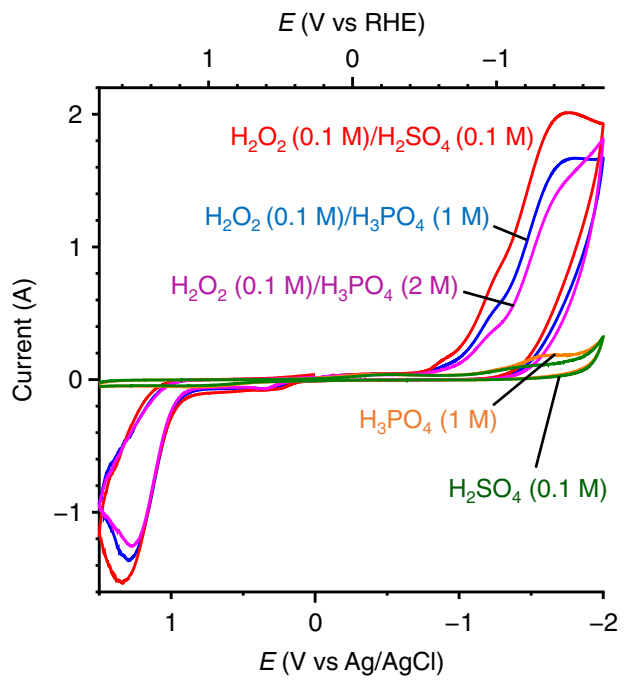

Fig. 3 CV charts measured on a GQDs-loaded grassy carbon electrode in the different solutions. The $\mathrm{pH}$ of the solutions is $\sim$, and all the measurements were carried out under $\mathrm{N}_{2}$ atmosphere with $0.1 \mathrm{M} \mathrm{Na}_{2} \mathrm{SO}_{4}$ and at a scan rate of $0.1 \mathrm{~V} \mathrm{~s}^{-1}$.

disproportionation even in the presence of $\mathrm{H}_{3} \mathrm{PO}_{4}$ (Eq. (6)). Therefore, the use of the all-organic $\mathrm{GQD} / \mathrm{g}-\mathrm{C}_{3} \mathrm{~N}_{4}$ catalyst, which is inactive for $\mathrm{H}_{2} \mathrm{O}_{2}$ disproportionation, together with $\mathrm{H}_{3} \mathrm{PO}_{4}$, which suppresses $\mathrm{H}_{2} \mathrm{O}_{2}$ reduction by the $\mathrm{CB} \mathrm{e}^{-}$, is effective for photocatalytic $\mathrm{H}_{2} \mathrm{O}_{2}$ splitting.

Stabilization of $\mathbf{H}_{2} \mathbf{O}_{2}$ by $\mathbf{H}_{3} \mathbf{P O}_{4} \cdot \mathrm{H}_{3} \mathrm{PO}_{4}$ is used as a stabilizer to suppress the disproportionation of $\mathrm{H}_{2} \mathrm{O}_{2}$ caused by metal cation impurities ${ }^{44,45}$, although the mechanism for their association has not been clarified yet ${ }^{46-48}$. The interaction between $\mathrm{H}_{2} \mathrm{O}_{2}$ and $\mathrm{H}_{3} \mathrm{PO}_{4}$ was confirmed by cyclic voltammetry $(\mathrm{CV})$ measurements. Figure 3 presents the CV curves obtained with a GQDsloaded glassy carbon electrode in a solution containing $0.1 \mathrm{M}$ $\mathrm{Na}_{2} \mathrm{SO}_{4}$ as an electrolyte. In $0.1 \mathrm{M} \mathrm{H}_{2} \mathrm{SO}_{4}(\mathrm{pH} \sim 1.0$ ), as denoted by a green line, the $\mathrm{CV}$ curve presents a weak cathodic current at $\sim-1.5 \mathrm{~V}$ (vs RHE), which is assigned to $\mathrm{H}^{+}$reduction, where no anodic current is observed. The $\mathrm{H}_{3} \mathrm{PO}_{4}$ solution $(1 \mathrm{M}, \mathrm{pH}$ 1.0) presents a similar CV curve (yellow line). Addition of $\mathrm{H}_{2} \mathrm{O}_{2}$ $(0.1 \mathrm{M})$ to the $\mathrm{H}_{2} \mathrm{SO}_{4}$ solution (red line) exhibits a strong cathodic current at $<-0.8 \mathrm{~V}$, which is assigned to $\mathrm{H}_{2} \mathrm{O}_{2}$ reduction (Eqs. (8) and $(9))^{49}$, whereas a strong anodic current is observed at $>1.2 \mathrm{~V}$, which is assigned to $\mathrm{H}_{2} \mathrm{O}_{2}$ oxidation (Eq. (3)). In contrast, as shown by the blue and purple lines, addition of $\mathrm{H}_{2} \mathrm{O}_{2}$ to the $\mathrm{H}_{3} \mathrm{PO}_{4}$ solution presents cathodic current, which is weaker than that obtained in the $\mathrm{H}_{2} \mathrm{O}_{2} / \mathrm{H}_{2} \mathrm{SO}_{4}$ mixture (red line). These data indicate that $\mathrm{H}_{2} \mathrm{O}_{2}$ interacts with $\mathrm{H}_{3} \mathrm{PO}_{4}$ and suppresses its reduction. As reported ${ }^{50}$, at this $\mathrm{pH}(\sim 1)$, phosphoric acid exists as a non-dissociated neutral $\mathrm{H}_{3} \mathrm{PO}_{4}$ form, where its mole ratio is $\sim 94 \%$ and a mole ratio of mono-deprotonated $\mathrm{H}_{2} \mathrm{PO}_{4}{ }^{-}$form is $\sim 6 \%$, suggesting that $\mathrm{H}_{2} \mathrm{O}_{2}$ interacts with the $\mathrm{H}_{3} \mathrm{PO}_{4}$ form.

Raman spectroscopy. The interaction between $\mathrm{H}_{2} \mathrm{O}_{2}$ and $\mathrm{H}_{3} \mathrm{PO}_{4}$ was further studied via Raman spectroscopy at $293 \mathrm{~K}$ (Fig. 4a). Pure water (purple) exhibits a strong band at $2800-3800 \mathrm{~cm}^{-1}$ for the $\mathrm{O}-\mathrm{H}$ stretching vibration of water, indicative of strong hydrogen $(\mathrm{H}-)$ bonding between the water molecules, as is schematically shown in Fig. 5a (left). The $\mathrm{H}_{2} \mathrm{O}_{2}$ solution (black) exhibits a weaker $\mathrm{O}-\mathrm{H}$ band because the interaction between $\mathrm{H}_{2} \mathrm{O}_{2}$ and water weakens the $\mathrm{H}$-bonding between the water molecules. The $\mathrm{H}_{3} \mathrm{PO}_{4}$ solution (orange) exhibits a much weaker $\mathrm{O}-\mathrm{H}$ band because, as shown in Fig. 5a (middle), $\mathrm{H}_{3} \mathrm{PO}_{4}$ strongly interacts with water ${ }^{50}$ $\mathbf{a}_{293 \mathrm{~K}}$
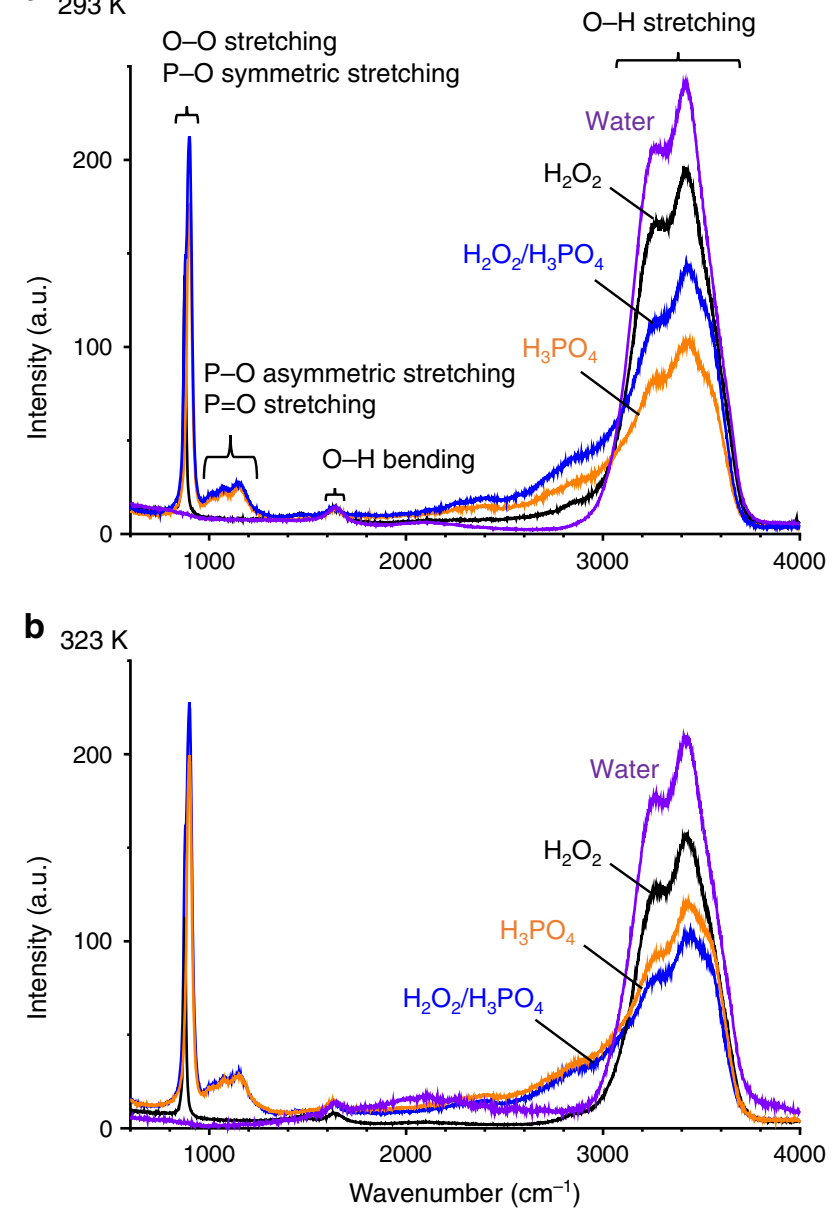

Fig. 4 Raman spectra (600-4000 $\mathrm{cm}^{-1}$ region) of the respective solutions. a $293 \mathrm{~K}$. b $323 \mathrm{~K}$. The $\mathrm{H}_{2} \mathrm{O}_{2}$ and $\mathrm{H}_{3} \mathrm{PO}_{4}$ concentrations are $2 \mathrm{M}$ and $4 \mathrm{M}$, respectively.

and significantly weakens the $\mathrm{H}$-bonding between the water molecules. The addition of $\mathrm{H}_{2} \mathrm{O}_{2}$ to the $\mathrm{H}_{3} \mathrm{PO}_{4}$ solution (blue), however, increases the $\mathrm{O}-\mathrm{H}$ band. This indicates that, as shown in Fig. 5a (right), $\mathrm{H}_{3} \mathrm{PO}_{4}$ interacts with $\mathrm{H}_{2} \mathrm{O}_{2}$ more strongly than with water owing to the $\mathrm{H}$-bonding interaction to form the $\mathrm{H}_{2} \mathrm{O}_{2}-\mathrm{H}_{2} \mathrm{PO}_{4}^{-}$bidentate complex with a structure similar to the urea- $\mathrm{H}_{2} \mathrm{PO}_{4}{ }^{-}$complex ${ }^{51}$. This may suppress the water- $\mathrm{H}_{3} \mathrm{PO}_{4}$ interaction and regenerate strong $\mathrm{H}$-bonding interaction between the water molecules. These data suggest that $\mathrm{H}_{3} \mathrm{PO}_{4}$ associates with $\mathrm{H}_{2} \mathrm{O}_{2}$ via $\mathrm{H}$-bonding to form a stabilized complex (Fig. 5a (right)), which may inhibit the $\mathrm{H}_{2} \mathrm{O}_{2}$ reduction by the $\mathrm{CB} \mathrm{e}^{-}$.

Figure 6a presents the Raman spectroscopy results of the respective solutions in the $850-950 \mathrm{~cm}^{-1}$ region measured at $293 \mathrm{~K}$. The $\mathrm{H}_{2} \mathrm{O}_{2}$ solution (top) exhibits a band at $875.6 \mathrm{~cm}^{-1}$, which is assigned to the $\mathrm{O}-\mathrm{O}$ stretching vibration of $\mathrm{H}_{2} \mathrm{O}_{2}{ }^{52}$. The $\mathrm{H}_{3} \mathrm{PO}_{4}$ solution (middle) exhibits a band at $899.0 \mathrm{~cm}^{-1}$ assigned to the $\mathrm{P}-\mathrm{O}$ symmetric stretching vibration of $\mathrm{H}_{3} \mathrm{PO}_{4}{ }^{53}$. The spectrum of the $\mathrm{H}_{2} \mathrm{O}_{2} / \mathrm{H}_{3} \mathrm{PO}_{4}$ mixture (bottom) can be deconvoluted into $\mathrm{O}-\mathrm{O}$ and $\mathrm{P}-\mathrm{O}$ stretching components. The $\mathrm{O}-\mathrm{O}$ band of the mixture appears at $874.6 \mathrm{~cm}^{-1}$, which lies at a lower wavenumber $\left(\Delta \widetilde{v}=-1.0 \mathrm{~cm}^{-1}\right)$ than that of the band of pure $\mathrm{H}_{2} \mathrm{O}_{2}\left(875.6 \mathrm{~cm}^{-1}\right)$. In addition, the $\mathrm{P}-\mathrm{O}$ band of the mixture appears at $899.0 \mathrm{~cm}^{-1}$, which also lies at a lower wavenumber $\left(\Delta \widetilde{v}=-0.7 \mathrm{~cm}^{-1}\right)$ than that of pure $\mathrm{H}_{3} \mathrm{PO}_{4}$ $\left(899.7 \mathrm{~cm}^{-1}\right)$. These data suggest that the lengths of the $\mathrm{O}-\mathrm{O}$ and $\mathrm{P}-\mathrm{O}$ bonds are extended by the $\mathrm{H}$-bonding between $\mathrm{H}_{2} \mathrm{O}_{2}$ and $\mathrm{H}_{3} \mathrm{PO}_{4}$ (Fig. 5a (right)). 
a

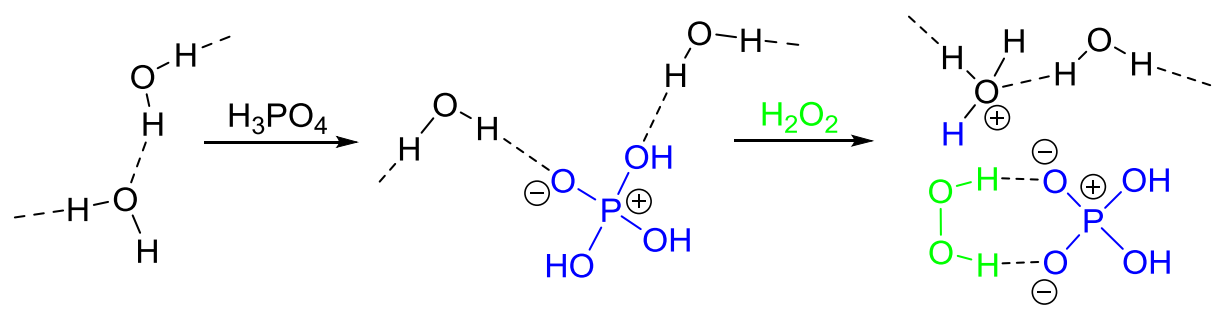

b

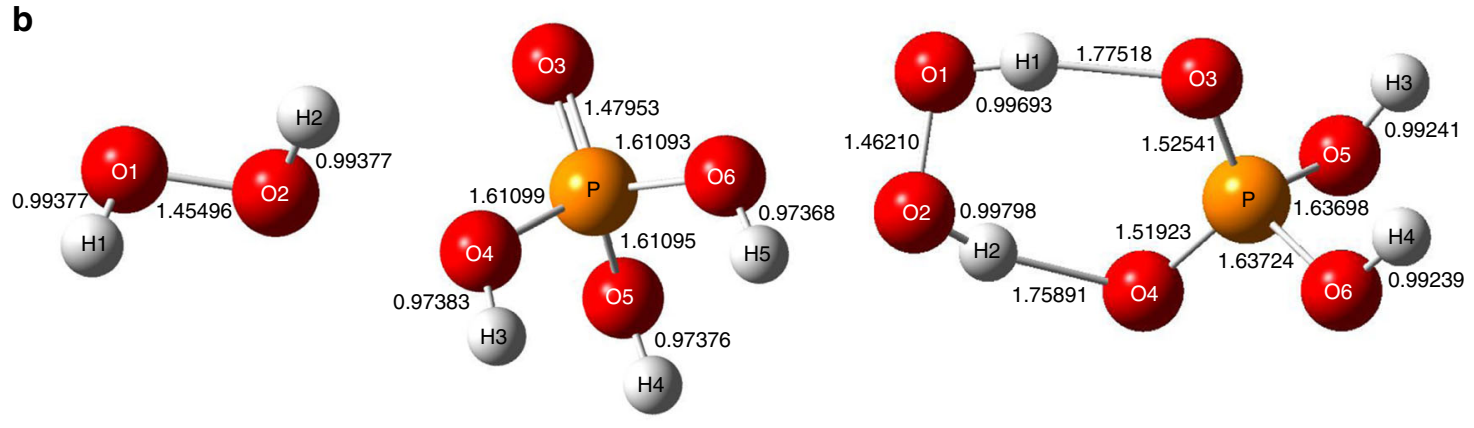

Fig. 5 Schematic representation of $\mathbf{H}$-bonding interaction and optimized structures of compounds. a Sequential change in $\mathrm{H}$-bonding interaction between water, $\mathrm{H}_{2} \mathrm{PO}_{4}^{-}$, and $\mathrm{H}_{2} \mathrm{O}_{2}$. b optimized structures of $\mathrm{H}_{2} \mathrm{O}_{2}, \mathrm{H}_{2} \mathrm{PO}_{4}^{-}$, and $\mathrm{H}_{2} \mathrm{O}_{2}-\mathrm{H}_{2} \mathrm{PO}_{4}^{-}$complex (DFT/B3LYP/6-31 G*(d), $\mathrm{PCM}$ : water).
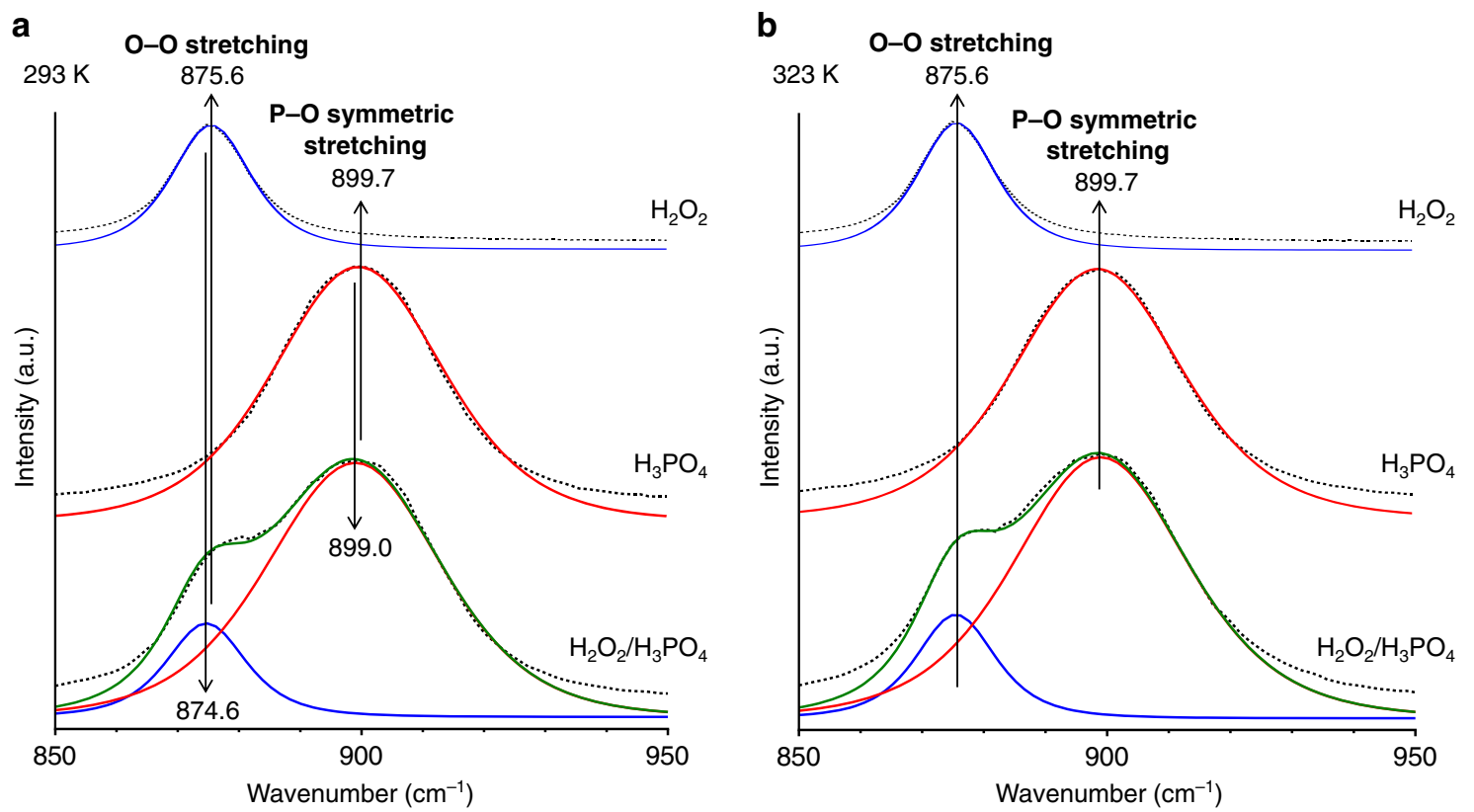

Fig. 6 Raman spectra (850-950 cm-1) of (top) $\mathrm{H}_{2} \mathrm{O}_{2}$, (middle) $\mathrm{H}_{3} \mathrm{PO}_{4}$, and (bottom) a mixture of $\mathrm{H}_{2} \mathrm{O}_{2}$ and $\mathrm{H}_{3} \mathrm{PO}_{4}$ measured at different temperatures. a $293 \mathrm{~K}$. b $323 \mathrm{~K}$. The $\mathrm{H}_{2} \mathrm{O}_{2}$ and $\mathrm{H}_{3} \mathrm{PO}_{4}$ concentrations are $2 \mathrm{M}$ and $4 \mathrm{M}$, respectively. The dots are the experimental data, and the solid lines are the deconvoluted components, where the green lines are the sum of the components.

Ab initio calculations. To obtain further information on the interaction between $\mathrm{H}_{2} \mathrm{O}_{2}$ and $\mathrm{H}_{3} \mathrm{PO}_{4}$, the structure of the $\mathrm{H}_{2} \mathrm{O}_{2}-\mathrm{H}_{2} \mathrm{PO}_{4}{ }^{-}$complex (Fig. $5 \mathrm{a}$ (right)) was calculated by density functional theory (DFT) using the polarizable continuum model (PCM) with water as the solvent (Supplementary Tables 3-6) ${ }^{54}$. Figure $5 \mathrm{~b}$ presents the optimized structures of $\mathrm{H}_{2} \mathrm{O}_{2}, \mathrm{H}_{3} \mathrm{PO}_{4}$, and the $\mathrm{H}_{2} \mathrm{O}_{2}-\mathrm{H}_{2} \mathrm{PO}_{4}^{-}$complex, and the lengths of the respective bonds. The $\mathrm{O}-\mathrm{O}$ bond length in the complex $(1.462 \AA)$ is longer than that in $\mathrm{H}_{2} \mathrm{O}_{2}(1.455 \AA)$. In addition, the lengths of the two $\mathrm{P}-\mathrm{O}$ bonds in the complex $(1.525 \AA$ (P-O3) and $1.519 \AA$ (P-O4)) are longer than those in $\mathrm{H}_{3} \mathrm{PO}_{4}(1.480 \AA$ ( $\left.\mathrm{P}-\mathrm{O} 3)\right)$, where the average $\mathrm{P}-\mathrm{O}$ lengths of the complex $(1.580 \AA)$ is also longer than those of $\mathrm{H}_{3} \mathrm{PO}_{4}(1.578 \AA$ ). The shortened lengths of the $\mathrm{O}-\mathrm{O}$ bond
( $\Delta=0.007 \AA$ ) and $\mathrm{P}$-O bonds $(\Delta=0.002 \AA$ ) by the H-bonding interaction agree reasonably with the lower wavenumber shift of the $\mathrm{O}-\mathrm{O}$ and $\mathrm{P}-\mathrm{O}$ stretching vibrations, as confirmed via Raman analysis (Fig. 6a). The DFT frequency calculations (Supplementary Table 2) reveal that the wavenumbers of the $\mathrm{O}-\mathrm{O}$ stretching in $\mathrm{H}_{2} \mathrm{O}_{2}$ and the complex are $947.7 \mathrm{~cm}^{-1}$ and $942.8 \mathrm{~cm}^{-155}$, respectively $\left(\Delta \widetilde{v}=-4.9 \mathrm{~cm}^{-1}\right)$, and the wavenumbers of the $\mathrm{P}-\mathrm{O}$ symmetric stretching in $\mathrm{H}_{3} \mathrm{PO}_{4}$ and the complex are $1075 \mathrm{~cm}^{-1}$ and $1039 \mathrm{~cm}^{-156}$, respectively $\left(\Delta \widetilde{v}=-36 \mathrm{~cm}^{-1}\right)$. Although the frequencies calculated by DFT are overestimated owing to the large anharmonicity of the high-frequency modes ${ }^{57,58}$, the lower wavenumber shifts of the $\mathrm{O}-\mathrm{O}$ and $\mathrm{P}-\mathrm{O}$ bonds caused by the $\mathrm{H}$ bonding interaction between $\mathrm{H}_{2} \mathrm{O}_{2}$ and $\mathrm{H}_{3} \mathrm{PO}_{4}$ are consistent 
with the Raman data (Fig. 6a). In addition, the two $\mathrm{O}-\mathrm{H} \cdots \mathrm{O}$ distances of the complex are $2.749 \AA(\mathrm{O} 1-\mathrm{H} 1 \cdots \mathrm{O} 3)$ and $2.733 \AA$ $(\mathrm{O} 2-\mathrm{H} 2 \cdots \mathrm{O} 4)$, indicative of strong and mostly electrostatic $\mathrm{H}$ bonding interaction between $\mathrm{H}_{2} \mathrm{O}_{2}$ and $\mathrm{H}_{3} \mathrm{PO}_{4}{ }^{59}$. Supplementary Fig. 5 summarizes the energy diagram for the frontier molecular orbitals $^{60}$ of the calculated models. The interaction of the highestoccupied molecular orbital (HOMO) of $\mathrm{H}_{2} \mathrm{PO}_{4}{ }^{-}$with the lowestunoccupied molecular orbital (LUMO) of $\mathrm{H}_{2} \mathrm{O}_{2}$ creates a frontier orbital of the complex (LUMO +1$)$ at an energy level higher than that of free $\mathrm{H}_{2} \mathrm{O}_{2}$, meaning that the $\mathrm{H}_{2} \mathrm{O}_{2}$ moiety of the complex is stabilized against its reduction upon external electron injection ${ }^{61}$. This is because the electron donation from $\mathrm{H}_{2} \mathrm{PO}_{4}{ }^{-}$to $\mathrm{H}_{2} \mathrm{O}_{2}$ leads to a decrease in the electron affinity of the $\mathrm{H}_{2} \mathrm{O}_{2}$ moiety and stabilizes its orbital. The result is consistent with the suppressed $\mathrm{H}_{2} \mathrm{O}_{2}$ reduction (Fig. 3) and the enhanced $\mathrm{H}_{2}$ evolution (Table 1 , entry 6) by the addition of $\mathrm{H}_{3} \mathrm{PO}_{4}$. Therefore, $\mathrm{H}_{3} \mathrm{PO}_{4}$ associates with $\mathrm{H}_{2} \mathrm{O}_{2}$ via $\mathrm{H}$-bonding and produce a stabilized complex (Fig. 5a (right) and Fig. 5b (right)). This interaction decreases the electron affinity of $\mathrm{H}_{2} \mathrm{O}_{2}$ and suppresses the $\mathrm{H}_{2} \mathrm{O}_{2}$ reduction by the $\mathrm{CB} \mathrm{e}^{-}$(Eqs. (8) and (9)), thus resulting in the promotion of $\mathrm{H}^{+}$reduction (Eq. (4)). It must be noted that addition of $\mathrm{H}_{3} \mathrm{PO}_{4}$ is necessary for efficient stabilization of $\mathrm{H}_{2} \mathrm{O}_{2}$; addition of phosphate salts is ineffective. As shown by entry 10 (Table 1), a $\mathrm{NaH}_{2} \mathrm{PO}_{4}(1 \mathrm{M})$ solution ( $\mathrm{pH} \sim 1$ ), when used for photoreaction, produces a lower amount of $\mathrm{H}_{2}$ than a $\mathrm{H}_{3} \mathrm{PO}_{4}(1$ M) solution (entry 6) although fully protonated $\mathrm{H}_{3} \mathrm{PO}_{4}$ species exist in both solutions. Alkaline metal cations interact with $\mathrm{H}_{2} \mathrm{O}_{2}$ in solution ${ }^{62}$. The $\mathrm{H}_{2} \mathrm{O}_{2}-\mathrm{Na}^{+}$interaction may weaken the $\mathrm{H}_{2} \mathrm{O}_{2}-\mathrm{H}_{2} \mathrm{PO}_{4}{ }^{-}$complex, probably resulting in the decreased $\mathrm{H}_{2}$ evolution activity.

Temperature effect. The stability of the $\mathrm{H}_{2} \mathrm{O}_{2}-\mathrm{H}_{2} \mathrm{PO}_{4}{ }^{-}$complex depends on the temperature of the solution. As shown by entry 6 (Table 1), the photoirradiation of $\mathrm{GQD}_{1} / \mathrm{g}-\mathrm{C}_{3} \mathrm{~N}_{4}$ at $293 \mathrm{~K}$ in a $\mathrm{H}_{2} \mathrm{O}_{2}$ solution containing $1 \mathrm{M} \mathrm{H}_{3} \mathrm{PO}_{4}$ produces $1.2 \mu \mathrm{mol}$ of $\mathrm{H}_{2}$. However, when the reaction is performed at $303 \mathrm{~K}$ (entry 11), the amount of $\mathrm{H}_{2}$ produced is decreased to $0.5 \mu \mathrm{mol}$, and further increase in the temperature $(313 \mathrm{~K}$ and $323 \mathrm{~K})$ does not produce $\mathrm{H}_{2}$ (entries 12 and 13), indicating that higher temperature is ineffective. To clarify the temperature effect on the $\mathrm{H}_{2} \mathrm{O}_{2}-\mathrm{H}_{2} \mathrm{PO}_{4}{ }^{-}$interaction, Raman spectroscopy was measured at a high temperature $(323 \mathrm{~K})$. As displayed in Fig. $4 \mathrm{~b}$ (orange), the $\mathrm{O}-\mathrm{H}$ band of water decreases by the addition of $\mathrm{H}_{3} \mathrm{PO}_{4}$; this is owing to the water- $\mathrm{H}_{3} \mathrm{PO}_{4} \mathrm{H}$-bonding interaction (Fig. 5a (middle)), similar to the case at $293 \mathrm{~K}$ (Fig. 4a). At $293 \mathrm{~K}$, the decreased $\mathrm{O}-\mathrm{H}$ band increases on the addition of $\mathrm{H}_{2} \mathrm{O}_{2}$; this is because the formation of the $\mathrm{H}_{2} \mathrm{O}_{2}-\mathrm{H}_{2} \mathrm{PO}_{4}{ }^{-}$complex regenerates the $\mathrm{H}$-bonding between the water molecules. However, at $323 \mathrm{~K}$, the addition of $\mathrm{H}_{2} \mathrm{O}_{2}$ to the $\mathrm{H}_{3} \mathrm{PO}_{4}$ solution barely increases the $\mathrm{O}-\mathrm{H}$ band, indicating that there is no $\mathrm{H}$-bonding interaction between $\mathrm{H}_{2} \mathrm{O}_{2}$ and $\mathrm{H}_{2} \mathrm{PO}_{4}{ }^{-}$. As displayed in Fig. 6a, the Raman spectrum of the $\mathrm{H}_{2} \mathrm{O}_{2} / \mathrm{H}_{3} \mathrm{PO}_{4}$ mixture measured at $293 \mathrm{~K}$ presents $\mathrm{O}-\mathrm{O}\left(874.6 \mathrm{~cm}^{-1}\right)$ and $\mathrm{P}-\mathrm{O}\left(899.0 \mathrm{~cm}^{-1}\right)$ bands, both of which lie at lower wavenumbers than those of only $\mathrm{H}_{2} \mathrm{O}_{2}\left(875.6 \mathrm{~cm}^{-1}\right)$ and $\mathrm{H}_{3} \mathrm{PO}_{4}\left(899.7 \mathrm{~cm}^{-1}\right)$, owing to the $\mathrm{H}_{2} \mathrm{O}_{2}-\mathrm{H}_{2} \mathrm{PO}_{4}{ }^{-}$complex formation. However, at $323 \mathrm{~K}$ (Fig. $6 \mathrm{~b}$ ), the $\mathrm{H}_{2} \mathrm{O}_{2} / \mathrm{H}_{3} \mathrm{PO}_{4}$ mixture shows $\mathrm{O}-\mathrm{O}\left(875.6 \mathrm{~cm}^{-1}\right)$ and $\mathrm{P}-\mathrm{O}$ $\left(899.7 \mathrm{~cm}^{-1}\right)$ bands at identical positions to those in $\mathrm{H}_{2} \mathrm{O}_{2}$ and $\mathrm{H}_{3} \mathrm{PO}_{4}$. These data suggest that the $\mathrm{H}_{2} \mathrm{O}_{2}-\mathrm{H}_{2} \mathrm{PO}_{4}{ }^{-}$complex is destabilized at higher temperatures because a rise in temperature increases the kinetic energy of the molecules and weakens their $\mathrm{H}$-bonding interaction ${ }^{63}$, as observed in several H-bonding systems such as dimethyl sulfoxide-water ${ }^{64}$ and urea-water ${ }^{65}$ at the similar temperature range $(283-333 \mathrm{~K})$. The weakened interaction at higher temperatures inevitably promotes $\mathrm{H}_{2} \mathrm{O}_{2}$ reduction (Eqs.
(8) and (9)) and, hence, decrease $\mathrm{H}_{2}$ generation (Eq. (4)). The photoreaction at a relatively lower temperature is therefore necessary for efficient $\mathrm{H}_{2}$ generation.

Effect of light wavelength. Visible-light irradiation is also necessary for this system. Figure $1 \mathrm{~d}$ shows the time course for the amount of $\mathrm{H}_{2}$ evolved during the photocatalytic $\mathrm{H}_{2} \mathrm{O}_{2}$ splitting over the GQD $/$ g- $\mathrm{C}_{3} \mathrm{~N}_{4}$ catalyst with $1 \mathrm{M} \mathrm{H}_{3} \mathrm{PO}_{4}$ at $293 \mathrm{~K}$. Further, the $\mathrm{H}_{2}$ selectivity is defined as the ratio of the amount of $\mathrm{H}_{2}$ evolved to that of the consumed $\mathrm{H}_{2} \mathrm{O}_{2}$ (Eq. (10)). Under visible light $(\lambda>420 \mathrm{~nm})$ exposure, as depicted by circle keys, the amount of $\mathrm{H}_{2}$ evolved increases almost linearly with time, and the $\mathrm{H}_{2}$ selectivity is almost constant even after prolonged photoirradiation. This indicates that the system consisting of the allorganic GQD 1 /g- $\mathrm{C}_{3} \mathrm{~N}_{4}$ catalyst and $\mathrm{H}_{3} \mathrm{PO}_{4}$ as a stabilizer at a low temperature stably promotes $\mathrm{H}_{2} \mathrm{O}_{2}$ splitting. In addition, as presented in Supplementary Fig. 6, the recovered GQD $1 / g-C_{3} N_{4}$ catalyst, when reused for further photoreactions, maintains the activity and the $\mathrm{H}_{2}$ selectivity, indicating that the catalyst is reusable without the loss of activity. However, the $\mathrm{H}_{2}$ selectivity is only $\sim 6 \%$, indicating that the $\mathrm{H}_{2} \mathrm{O}_{2}$ reduction (Eqs. (8) and (9)) still occurs more efficiently than the $\mathrm{H}^{+}$reduction (Eq. (4)) even in the presence of $\mathrm{H}_{3} \mathrm{PO}_{4}$.

$$
\mathrm{H}_{2} \operatorname{selectivity}(\%)=\frac{\left[\mathrm{H}_{2} \text { evolved }(\mu \mathrm{mol})\right]}{\left[\mathrm{H}_{2} \mathrm{O}_{2} \operatorname{consumed}(\mu \mathrm{mol})\right]} \times 100
$$

The square keys in Fig. 1d denote the results obtained under irradiation of the entire wavelength light $(\lambda>300 \mathrm{~nm})$ from the solar simulator (Supplementary Fig. 7). The amount of $\mathrm{H}_{2}$ evolved is much smaller than that under $\lambda>420 \mathrm{~nm}$ irradiation. As summarized in Table 1 (entry 14), $\lambda>300 \mathrm{~nm}$ irradiation for $6 \mathrm{~h}$ produces a larger amount of $\mathrm{O}_{2}(22 \mu \mathrm{mol})$ than the $\lambda>420$ $\mathrm{nm}$ irradiation $(7.7 \mu \mathrm{mol}$, entry 5$)$. This indicates that UV irradiation enhances the catalyst photoexcitation and efficiently promotes $\mathrm{H}_{2} \mathrm{O}_{2}$ oxidation by the $\mathrm{VB} \mathrm{h}^{+}$(Eq. (3)), clearly suggesting that UV irradiation suppresses $\mathrm{H}^{+}$reduction (Eq. (4)). The $\lambda>300 \mathrm{~nm}$ irradiation decomposes a larger amount of $\mathrm{H}_{2} \mathrm{O}_{2}$ (127 $\mu \mathrm{mol})$ than the $\lambda>420 \mathrm{~nm}$ irradiation $(20 \mu \mathrm{mol}$, entry 6$)$; this is owing to the photodecomposition of $\mathrm{H}_{2} \mathrm{O}_{2}$ by the absorbed UV light (Eq. (7)), as confirmed by the absorption spectra of the $\mathrm{H}_{2} \mathrm{O}_{2}$ solution in the UV region (Supplementary Fig. 8). This suggests that the $\mathrm{H}_{2} \mathrm{O}_{2}-\mathrm{H}_{2} \mathrm{PO}_{4}{ }^{-}$complex absorbs UV light and undergoes destabilization. The weakened $\mathrm{H}$-bonding of the complex may therefore inevitably promote $\mathrm{H}_{2} \mathrm{O}_{2}$ reduction (Eqs. (8) and (9)), thus inhibiting the $\mathrm{H}^{+}$reduction (Eq. (4)). As displayed in Fig. 1d (square), the $\mathrm{H}_{2}$ selectivity with $\lambda>300$ $\mathrm{nm}$ irradiation is only $\sim 0.5 \%$ owing to the accelerated $\mathrm{H}_{2} \mathrm{O}_{2}$ decomposition, indicating that visible-light irradiation is necessary for efficient photocatalytic $\mathrm{H}_{2} \mathrm{O}_{2}$ splitting. Even under visible-light irradiation, the $\mathrm{H}_{2}$ selectivity is $\sim 6 \%$; therefore, further selectivity enhancement is necessary for practical applications. Nevertheless, the successful example presented here based on the combination of an all-organic photocatalyst and $\mathrm{H}_{3} \mathrm{PO}_{4}$ as a stabilizer under sunlight illumination presents significant potential for photocatalytic $\mathrm{H}_{2} \mathrm{O}_{2}$ splitting.

\section{Discussion}

Visible-light irradiation of the all-organic GQD/g- $\mathrm{C}_{3} \mathrm{~N}_{4}$ catalyst in a $\mathrm{H}_{2} \mathrm{O}_{2}$ solution containing $\mathrm{H}_{3} \mathrm{PO}_{4}$ at a relatively low temperature $(\sim 293 \mathrm{~K})$ could successfully promote $\mathrm{H}_{2}$ generation by photocatalytic $\mathrm{H}_{2} \mathrm{O}_{2}$ splitting. The Raman spectroscopy and DFT calculations revealed that $\mathrm{H}_{3} \mathrm{PO}_{4}$ associates with $\mathrm{H}_{2} \mathrm{O}_{2}$ via $\mathrm{H}$ bonding interaction and forms a $\mathrm{H}_{2} \mathrm{O}_{2}-\mathrm{H}_{2} \mathrm{PO}_{4}{ }^{-}$complex at a low temperature. This decreases the electron affinity of $\mathrm{H}_{2} \mathrm{O}_{2}$ and suppresses its reduction, thus promoting $\mathrm{H}^{+}$reduction $\left(\mathrm{H}_{2}\right.$ 
generation). The present system stably produces $\mathrm{H}_{2}$ even after prolonged photoirradiation, and the catalyst is reusable without the loss of activity and $\mathrm{H}_{2}$ selectivity. This photocatalytic system offers several advantages: a metal-free photocatalyst and inexpensive acid $\left(\mathrm{H}_{3} \mathrm{PO}_{4}\right)$ can be used for the reaction; visible light, a main constituent of sunlight irradiation, can be used as the light source; and on-site $\mathrm{H}_{2}$ generation from a transportable and storable energy carrier $\left(\mathrm{H}_{2} \mathrm{O}_{2}\right)$ can be achieved. At present, $\mathrm{H}_{2}$ selectivity is only $\sim 6 \%$ relative to the amount of $\mathrm{H}_{2} \mathrm{O}_{2}$ consumed, and further improvement of its selectivity is necessary for practical applications. Nevertheless, the successful example presented here based on an all-organic catalyst with $\mathrm{H}_{3} \mathrm{PO}_{4}$ as a stabilizer may contribute to the design of a highly efficient system for the on-site photocatalytic generation of $\mathrm{H}_{2}$ from a $\mathrm{H}_{2} \mathrm{O}_{2}$ solution.

\begin{abstract}
Methods
Catalyst preparation. The $\mathrm{g}-\mathrm{C}_{3} \mathrm{~N}_{4}$ powder was prepared by calcination of melamine at $823 \mathrm{~K}$ (heating rate: $2.3 \mathrm{~K} \mathrm{~min}^{-1}$, holding time: $4 \mathrm{~h}$ ) ${ }^{27}$. The GQDs solution was synthesized as follows: ${ }^{30}$ pyrene $(2 \mathrm{~g})$ was stirred in concentrated $\mathrm{HNO}_{3}$ $(160 \mathrm{~mL})$ at $353 \mathrm{~K}$ for $12 \mathrm{~h}$. Water $(2 \mathrm{~L})$ was added to the resultant, and the solids formed were recovered by filtration. The solids were dispersed in hydrazine hydrate solution $(1.0 \mathrm{M}, 40 \mathrm{~mL})$, ultrasonicated for $2 \mathrm{~h}$, and left in an autoclave at $423 \mathrm{~K}$ for $10 \mathrm{~h}$. Filtration of the resultant by a microporous membrane afforded a $0.5-\mathrm{g} \mathrm{L}^{-1}$ GQDs solution. The GQD $/$ g- $\mathrm{C}_{3} \mathrm{~N}_{4}$ catalysts $[x(\mathrm{wt} \%)=0.5,1.0,3.0$, and 5.0$]$ were prepared as follows: $\mathrm{g}-\mathrm{C}_{3} \mathrm{~N}_{4}(0.4 \mathrm{~g})$ was added to $40 \mathrm{~mL}$ of the GQDs solution $(0.05$, $0.1,0.3$, and $\left.0.5 \mathrm{~g} \mathrm{~L}^{-1}\right)$ and stirred for $1 \mathrm{~h}$ at $298 \mathrm{~K}$. The mixture was left in an autoclave at $423 \mathrm{~K}$ for $4 \mathrm{~h}$. The solids were recovered by centrifugation, washed with water, and dried at $353 \mathrm{~K}$, affording $\mathrm{GQD}_{x} / \mathrm{g}-\mathrm{C}_{3} \mathrm{~N}_{4}$ as brown powders. A Pt/g$\mathrm{C}_{3} \mathrm{~N}_{4}$ catalyst (Pt loading: $0.3 \mathrm{wt} \%$ ) was prepared as follows: ${ }^{33} \mathrm{~g}-\mathrm{C}_{3} \mathrm{~N}_{4}(1.0 \mathrm{~g}$ ) was added to water $(30 \mathrm{~mL})$ containing $\mathrm{H}_{2} \mathrm{PtCl}_{6} \cdot 6 \mathrm{H}_{2} \mathrm{O}(8.0 \mathrm{mg})$ and evaporated with vigorous stirring at $373 \mathrm{~K}$. The obtained powders were reduced under $\mathrm{H}_{2}$ flow $\left(0.1 \mathrm{~mL} \mathrm{~min}^{-1}\right)$ at $673 \mathrm{~K}$ (heating rate: $10 \mathrm{~K} \mathrm{~min}^{-1}$, holding time: $2 \mathrm{~h}$ ).
\end{abstract}

Photoreaction. $\mathrm{H}_{2}$ generation from a TEOA solution was performed in a closed system $(0.1 \mathrm{MPa})$. The catalyst $(100 \mathrm{mg})$ was added to a $10 \mathrm{vol} \%$ TEOA solution $(30 \mathrm{~mL})$ within a glass tube $(\varphi 35 \mathrm{~mm}$; capacity, $50 \mathrm{~mL})$. The tube was sealed with a rubber cap and ultrasonicated for $5 \mathrm{~min}$, and Ar gas was bubbled through the solution for $10 \mathrm{~min}$. The tube was photoirradiated $(\lambda>420 \mathrm{~nm})$ using a $2-\mathrm{kW}$ Xe lamp (USHIO Inc.) with magnetic stirring at room temperature. After the reaction, the amount of $\mathrm{H}_{2}$ formed was determined by gas chromatography-thermal conductivity detector (GC-TCD) (Shimadzu; GC-8A). Photocatalytic $\mathrm{H}_{2} \mathrm{O}_{2}$ splitting was performed in a closed gas circulation system connected to GC-TCD ${ }^{66}$. The catalyst $(200 \mathrm{mg})$ was added to a $\mathrm{H}_{2} \mathrm{O}_{2}$ solution $(1 \mathrm{mmol}, 100 \mathrm{~mL})$ within a quartz cell. The cell was connected to a gas circulation system, and the system was depressurized to $3 \mathrm{kPa}$ after repeated Ar purging. The cell was immersed in a temperature-controlled water bath $( \pm 0.1 \mathrm{~K})$ and photoirradiated at $\lambda>420 \mathrm{~nm}$ using a solar simulator equipped with AM1.5 G filter (SAN-EI Electric Inc.; XES$40 \mathrm{~S} 3$, 1-sun) with magnetic stirring ${ }^{12}$. The amounts of $\mathrm{H}_{2} \mathrm{O}_{2}$ in the solutions were determined by redox titration with $\mathrm{KMnO}_{4}$

Analysis. The electrochemical measurements were performed in a conventional three-electrode cell using an electrochemical system (ALS700E, BAS Inc.), where $\mathrm{Ag} / \mathrm{AgCl}$ and $\mathrm{Pt}$ wire electrodes were used as the reference and counter electrodes, respectively ${ }^{66}$. For the photocurrent measurements, a catalyst-loaded FTO glass was used as the working electrode. Catalyst $(20 \mathrm{mg})$ was added to a mixture of water $(4 \mathrm{~mL}), 2$-propanol $(1.5 \mathrm{~mL})$, and $5 \mathrm{wt} \%$ Nafion solution $(100 \mu \mathrm{L})^{67}$, and ultrasonicated for $10 \mathrm{~min}$. The slurry was placed onto an FTO glass and dried at room temperature. The film was formed to $0.5 \mathrm{~cm} \times 0.5 \mathrm{~cm}$ square, where the undeposited parts were coated with an epoxy resin. For the CV measurements, a glassy carbon electrode loaded with GQD was used as the working electrode, where the GQD solution was placed on the electrode and dried at room temperature. All the measurements were performed after $\mathrm{N}_{2}$ bubbling through the solution for $1 \mathrm{~h}$. Raman spectra were measured on a confocal Raman microscope (LabRAM HR800 , HORIBA) with a YAG laser (532 nm line) as the excitation source, where the laser power was $100 \mathrm{~mW}$ and the total data accumulation time was $100 \mathrm{~s}$, respectively. DR UV-vis, XRD, SEM, and TEM observations were performed according to the procedures described in the literature ${ }^{12}$.

Computational details. The molecular structures were optimized by the B3LYP functional (B3LYP/6-31G*(d)) using the polarizable continuum model (PCM) with water as the solvent ${ }^{54}$ in the Gaussian 03 program. Cartesian coordinates for the models used are summarized at the end of the Supplementary Material.

\section{Data availability}

All experimental data within the article and its Supplementary Information are available from the corresponding author upon reasonable request.

Received: 24 January 2020; Accepted: 17 June 2020; Published online: 07 July 2020

\section{References}

1. Concepcion, J. J., House, R. L., Papanikolas, J. M. \& Meyer, T. J. Chemical approaches to artificial photosynthesis. Proc. Natl Acad. Sci. USA 109, 15560-15564 (2012)

2. Lewis, N. S. Developing a scalable artificial photosynthesis technology through nanomaterials by design. Nat. Nanotechnol. 11, 1010-1019 (2016).

3. Chen, S., Takata, T. \& Domen, K. Particulate photocatalysts for overall water splitting. Nat. Rev. Mater. 2, 1-17 (2017).

4. Hisatomi, T. \& Domen, K. Reaction systems for solar hydrogen production via water splitting with particulate semiconductor photocatalysts. Nat. Catal. 2, 387-399 (2019).

5. Kudo, A. \& Miseki, Y. Heterogeneous photocatalyst materials for water splitting. Chem. Soc. Rev. 38, 253-278 (2009).

6. Teichmann, D., Arlt, W. \& Wasserscheid, P. Liquid organic hydrogen carriers as an efficient vector for the transport and storage of renewable energy. Int. J. Hydrog. Energy 37, 18118-18132 (2012).

7. Guo, J. \& Chen, P. Catalyst: $\mathrm{NH}_{3}$ as an energy carrier. Chem 3, 709-712 (2017).

8. Fukuzumi, S. Production of Liquid Solar Fuels and Their Use in fuel cells. Joule 1, 689-738 (2017).

9. Fukuzumi, S., Lee, Y. M. \& Nam, W. Solar-driven production of hydrogen peroxide from water and dioxygen. Chem. Eur. J. 24, 5016-5031 (2018).

10. Haider, Z., Cho, H.-I., Moon, G.-H. \& Kim, H -I. Minireview: selective production of hydrogen peroxide as a clean oxidant over structurally tailored carbon nitride photocatalysts. Catal. Today 335, 55-64 (2019).

11. Hou, H., Zeng, X., \& Zhang, X. Production of hydrogen peroxide through photocatalytic processes: a critical review of recent advances. Angew. Chem. Int. Ed. https://doi.org/10.1002/anie.201911609 (2019).

12. Shiraishi, Y. et al. Resorcinol-formaldehyde resins as metal-free semiconductor photocatalysts for solar-to-hydrogen peroxide energy conversion. Nat. Mater. 18, 985-993 (2019).

13. Qi, Y. et al. Redox-based visible-light-driven $\mathrm{z}$-scheme overall water splitting with apparent quantum efficiency exceeding 10\%. Joule 2, 2393-2402 (2018).

14. Shiraishi, Y. et al. Highly selective production of hydrogen peroxide on graphitic carbon nitride photocatalyst activated by visible light. ACS Catal. 3, 774-780 (2014).

15. Jaouen, F. \& Dodelet, J. P. $\mathrm{O}_{2}$ reduction mechanism on non-noble metal catalysts for PEN fuel cells part I: experimental rates of $\mathrm{O}_{2}$ electroreduction, $\mathrm{H}_{2} \mathrm{O}_{2}$ electroreduction, and $\mathrm{H}_{2} \mathrm{O}_{2}$ disproportionation. J. Phys. Chem. C 113, 15422-15432 (2009)

16. Li, Z., Kong, C. \& Lu, G. Visible photocatalytic water splitting and photocatalytic two-electron oxygen formation over $\mathrm{Cu}$ - and $\mathrm{Fe}$-doped $\mathrm{g}-\mathrm{C}_{3} \mathrm{~N}_{4}$. J. Phys. Chem. C 120, 56-63 (2016).

17. Sahel, K. et al. Hydrogen peroxide and photocatalysis. Appl. Catal. B Environ. 188, 106-112 (2016).

18. Goldstein, S., Aschengrau, D., Diamant, Y. \& Rabani, J. Photolysis of aqueous $\mathrm{H}_{2} \mathrm{O}_{2}$ : quantum yield and applications for polychromatic UV actinometry in photoreactors. Environ. Sci. Technol. 41, 7486-7490 (2007).

19. Bockris, J. O. 'M. \& Oldfield, L. F. The oxidation-reduction reactions of hydrogen peroxide at inert metal electrodes and mercury cathodes. Trans. Faraday Soc. 51, 249-259 (1955).

20. Wang, X. et al. A metal-free polymeric photocatalyst for hydrogen production from water under visible light. Nat. Mater. 8, 76-80 (2009).

21. Wang, L. et al. Gram-scale synthesis of single-crystalline graphene quantum dots with superior optical properties. Nat. Commun. 5, 5357-5366 (2014).

22. Min, S., Hou, J., Lei, Y., Ma, X. \& Lu, G. Facile one-step hydrothermal synthesis toward strongly coupled $\mathrm{TiO}_{2}$ /graphene quantum dots photocatalysts for efficient hydrogen evolution. Appl. Surf. Sci. 396, 1375-1382 (2017).

23. Melo, Jr,M. A. \& Osterloh, F. E. Defect states control effective band gap and photochemistry of graphene quantum dots. ACS Appl. Mater. Interfaces 10, 27195-27204 (2018).

24. Gao, Y. et al. Graphene quantum-dot-modified hexagonal tubular carbon nitride for visible-light photocatalytic hydrogen evolution. ChemCatChem 10, 1330-1335 (2018).

25. Kim, N. H., Lim, J. H., Kim, S. Y. \& Chang, E. G. Effect of phosphoric acid stabilizer on copper and tantalum nitride. CMP 57, 4601-4604 (2003).

26. Wegner, P. C. Hydrogen peroxide stabilizer and resulting product and applications. US patent US20030151024 A1 (2003). 
27. Yan, S. C., Li, Z. S. \& Zou, Z. G. Photodegradation performance of $\mathrm{g}^{-\mathrm{C}_{3} \mathrm{~N}_{4}}$ fabricated by directly heating melamine. Langmuir 25, 10397-10401 (2009)

28. Yu, Y., Ren, J. \& Meng, M. Photocatalytic hydrogen evolution on graphene quantum dots anchored $\mathrm{TiO}_{2}$ nanotube-array. Int. J. Hydrog. Energy 38, 12266-12272 (2013).

29. Wang, R. et al. Graphene quantum dots modified $\mathrm{g}-\mathrm{C}_{3} \mathrm{~N}_{4}$ for enhanced photocatalytic oxidation of ammonia performance. RSC Adv. 7, 51687-51694 (2017).

30. Pan, D. et al. Efficient separation of electron-hole pairs in graphene quantum dots by $\mathrm{TiO}_{2}$ heterojunctions for dye degradation. ACS Sustain. Chem. Eng. 3, 2405-2413 (2015).

31. Zou, J. P. et al. Synthesis and efficient visible light photocatalytic $\mathrm{H}_{2}$ evolution of a metal-free $\mathrm{g}-\mathrm{C}_{3} \mathrm{~N}_{4}$ /graphene quantum dots hybrid photocatalyst. Appl. Catal. B Environ. 193, 103-109 (2016).

32. Liu, J. et al. Graphene quantum dots modified mesoporous graphite carbon nitride with significant enhancement of photocatalytic activity. Appl. Catal. B Environ. 207, 429-437 (2017).

33. Shiraishi, Y. et al. Platinum nanoparticles strongly associated with graphitic carbon nitride as efficient co-catalysts for photocatalytic hydrogen evolution under visible light. Chem. Commun. 50, 15255-15258 (2014).

34. Wang, Q. et al. Scalable water splitting on particulate photocatalyst sheets with a solar-to-hydrogen energy conversion efficiency exceeding 1\%. Nat. Mater. 15, 611-615 (2016).

35. Shiraishi, Y. et al. Sunlight-driven hydrogen peroxide production from water and molecular oxygen by metal-free photocatalysts. Angew. Chem. Int. Ed. 53, 13454-13459 (2014).

36. Achenbach, K. Process for etching copper printed circuits. US patent US3373113A (1968).

37. Pougherty, E. F. Stabilized hydrogen peroxide. US patent US4981662A (1991).

38. Hooper, G. W. Catalytic production of hydrogen peroxide from its elements. US patent US3336112A (1967)

39. Lee, H. H. B., Park, A. H. \& Oloman, C. Stability of hydrogen peroxide in sodium carbonate solution. Tappi J. 83, 1-9 (2000)

40. Fuku, K. et al. Photoelectrochemical hydrogen peroxide production from water on a $\mathrm{WO}_{3} / \mathrm{BiVO}_{4}$ photoanode and from $\mathrm{O}_{2}$ on an $\mathrm{Au}$ cathode without external bias. Chem. Asian J. 12, 1111-1119 (2017).

41. Baum, G. Stabilized peroxide solution. US patent US1758920A (1930).

42. Weber, F. W. Stable product containing hydrogen peroxide and method of making the same. US patent US1210570A (1917)

43. Malin, M. J. \& Sclafani, L. D. Stabilized aqueous hydrogen peroxide solution. US patent US4744968A. (1988).

44. Greenspan, F. P. Method of improving stability of concentrated hydrogen peroxide in contact with stainless and aluminum alloys. US patent US2782100A (1957).

45. Shimokawa, S., Namikawa, K. \& Murakami, S. Stabilized refined aqueous hydrogen peroxide solution. Jpn. Kokai Tokkyo Koho JP07-081906A (1995).

46. Roth, Jr,E. M. \& Shanley, E. S. Stability of Pure Hydrogen Peroxide. Ind. Eng. Chem. 45, 2343-2349 (1953).

47. Sun, H., Leonard, J. J. \& Shalit, H. Hydrogen peroxide production. US patent US4393038A (1983).

48. Shang, M., Noël, T., Su, Y. \& Hessel, V. High pressure direct synthesis of adipic from cyclohexene and hydrogen peroxide via capillary microreactors. Ind. Eng. Chem. Res. 55, 2669-2676 (2016).

49. Patra, S. \& Munichandraiah, N. Electrochemical reduction of hydrogen peroxide on stainless steel. J. Chem. Sci. 121, 6753-683 (2009).

50. Śmiechowski, M., Gojto, E. \& Stangret, J. Systematic study of hydration patterns of phosphoric(V) Acid and its mono-, di-, and tripotassium salts in aqueous solution. J. Phys. Chem. B 113, 7650-7661 (2009).

51. Kostansek, E. C. \& Busing, W. R. A single-crystal neutron-diffraction study of urea-phosphoric acid. Acta Crystallogr. B 28, 2454-2459 (1972).

52. Moreno, T. et al. Quantitative raman determination of hydrogen peroxide using the solvent as international standard: online application in the direct synthesis of hydrogen peroxide. Chem. Eng. J. 166, 1061-1065 (2011).

53. Rudolph, W. W. Raman- and infrared-spectroscopic investigations of dilute aqueous phosphoric acid solutions. Dalton Trans. 39, 9642-9653 (2010).

54. Cossi, M., Barone, V., Cammi, R. \& Tomasi, J. Ab initio study of solvated molecules: a new implementation of the polarizable continuum model. Chem. Phys. Lett. 255, 327-335 (1996).

55. Gonzalez, L., Mo, O. \& Yanez, M. High-level ab initio versus D. F. T. calculations on $\left(\mathrm{H}_{2} \mathrm{O}_{2}\right)_{2}$ and $\mathrm{H}_{2} \mathrm{O}_{2}-\mathrm{H}_{2} \mathrm{O}$ complexes as prototypes of multiple hydrogen bond systems. J. Comput. Chem. 18, 1124-1135 (1997).

56. Ahmed, A. B. et al. Crystal structure, vibrational spectra and theoretical studies of l-histidinium dihydrogen phosphate-phosphoric acid. J. Mol. Struct. 920, 1-7 (2009).

57. EI-Azhary, A. A. \& Suter, H. U. Comparison between optimized geometries and vibrational frequencies calculated by DFT methods. J. Phys. Chem. 100, 15056-15063 (1996).

58. Dkhissi, A., Adamowickz, L. \& Maes, G. Density functional theory study of the hydrogen-bonded pyridine- $\mathrm{H}_{2} \mathrm{O}$ complex: a comparison with $\mathrm{RHF}$ and
MP2 methods and with experimental data. J. Phys. Chem. A 104, 2112-2119 (2000).

59. Jeffrey, G. A. An Introduction to Hydrogen Bonding. (Oxford University Press, New York, 1997).

60. Fukui, K. Role of frontier orbitals in chemical reactions. Science 218, 747-754 (1982).

61. Heinrich, N., Koch, W. \& Frenking, G. On the use of Koopmans' theorem to estimate negative electron affinities. Chem. Phys. Lett. 124, 20-25 (1986).

62. Matheson, N. R., Wong, P. S., Schuyler, M. \& Travis, J. Interaction of human a-1-proteinase inhibitor with neutrophil myeloperoxidase. Biochemistry 20, 331-336 (1981)

63. Dougherty, R. C. Temperature and pressure dependence of hydrogen bond strength: a perturbation molecular orbital approach. J. Chem. Phys. 109, 7372-7378 (1998).

64. Oh, K. I., Rajesh, K., Stanton, J. F. \& Baiz, C. R. Quantifying hydrogen-bond populations in dimethyl sulfoxide/water mixtures. Angew. Chem. Int. Ed. 56, 11375-11379 (2017)

65. Mafy, N. N., Afrin, T., Rahman, M. M., Mollah, M. Y. A. \& Susan, M. A. B. H. Effect of temperature perturbation on hydrogen bonding in aqueous solutions of different urea concentrations. RSC Adv. 5, 59263-59272 (2015).

66. Shiraishi, Y. et al. Photocatalytic dinitrogen fixation with water on bismuth oxychloride in chloride solutions for solar-to-chemical energy conversion. $J$. Am. Chem. Soc. 142, 7574-7583 (2020)

67. Wang, X., Cheng, J., Yu, H. \& Yu, J. A facile hydrothermal synthesis of carbon dots modified g- $\mathrm{C}_{3} \mathrm{~N}_{4}$ for enhanced photocatalytic $\mathrm{H}_{2}$-evolution performance. Dalton Trans. 46, 6417-6424 (2017).

\section{Acknowledgements}

This work was supported by the Precursory Research for Embryonic Science and Technology (PRESTO) program (JPMJPR1442) under the supervision of the Japan Science and Technology Agency (JST). The part of this work was supported by Grant-in Aid for Scientific Research on Innovative Areas (No. 20H05100) from the Ministry of Education, Culture, Sports, Science and Technology, Japan (MEXT). We thank Y. Kitagawa at the Division of Chemical Engineering, Graduate School of Engineering Science, Osaka University for his helpful comments in the DFT calculations.

\section{Author contributions}

Y.S. directed this project and conceived the experiment. Y.U., A.S., and T.H. conducted the experimental work and analyzed the data. S.H. performed the TEM observations. The manuscript was written by Y.S. and Y.U. with contributions from the other coauthors. All authors have given approval to the final version of the manuscript.

\section{Competing interests}

The authors declare no competing interests.

\section{Additional information}

Supplementary information is available for this paper at https://doi.org/10.1038/s41467 020-17216-2.

Correspondence and requests for materials should be addressed to Y.S.

Peer review information Nature Communications thanks Natalia Martsinovich, Jingsan $\mathrm{Xu}$, and other, anonymous, reviewers for their contributions to the peer review of this work. Peer review reports are available.

Reprints and permission information is available at http://www.nature.com/reprints

Publisher's note Springer Nature remains neutral with regard to jurisdictional claims in published maps and institutional affiliations.

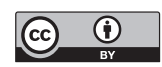

Open Access This article is licensed under a Creative Commons Attribution 4.0 International License, which permits use, sharing, adaptation, distribution and reproduction in any medium or format, as long as you give appropriate credit to the original author(s) and the source, provide a link to the Creative Commons license, and indicate if changes were made. The images or other third party material in this article are included in the article's Creative Commons license, unless indicated otherwise in a credit line to the material. If material is not included in the article's Creative Commons license and your intended use is not permitted by statutory regulation or exceeds the permitted use, you will need to obtain permission directly from the copyright holder. To view a copy of this license, visit http://creativecommons.org/ licenses/by/4.0/.

(C) The Author(s) 2020 